\title{
Consensus on the Use of Hyaluronic Acid Fillers from the Cohesive Polydensified Matrix Range: Best Practice in Specific Facial Indications
}

\author{
Jani van Loghem (D) \\ Sonja Sattler ${ }^{2}$ \\ Gabriela Casabona ${ }^{3}$ \\ Sebastian Cotofana ${ }^{4}$ \\ Sabrina Guillen Fabi ${ }^{5}$ \\ Kate Goldie ${ }^{6}$ \\ Uliana Gout ${ }^{7}$ \\ Martina Kerscher ${ }^{8}{ }^{8}$ \\ Ting Song Lim (D) \\ Carla de Sanctis Pecora (iD) 10 \\ Gerhard Sattler ${ }^{2}$ \\ Ada Trindade de Almeida " \\ RungsimaWanitphakdeedecha (iD) ${ }^{12}$ \\ PhilipWerschler ${ }^{13}$ \\ TatjanaPavicic $^{14}$ \\ 'Falck Clinic, Aesthetic Medicine Centre, \\ Amsterdam, the Netherlands; \\ ${ }^{2}$ Rosenpark Clinic, Darmstadt, Germany; \\ ${ }^{3}$ Ocean Clinic, Marbella, Spain; ${ }^{4}$ Albany \\ Medical College, Albany, NY, USA; \\ ${ }^{5}$ Cosmetic Laser Dermatology and \\ University of California, San Diego, CA, \\ USA; 'European Medical Aesthetics Ltd, \\ London, UK; ${ }^{7}$ Aesthetic Medicine Clinic, \\ London, UK; ${ }^{8}$ University of Hamburg, \\ Hamburg, Germany; ${ }^{9}$ Clique Clinic, Kuala \\ Lumpur, Malaysia; ${ }^{10}$ Dermatologie- \\ Clínica, Cirurgia, Cosmiatria e Laser, São \\ Paulo, Brazil; " Clínica de Dermatologia \\ do Hospital do Servidor Público \\ Municipal de São Paulo, São Paulo, Brazil; \\ 12iSKY Innovative Skin \& Laser Surgery \\ Center, Bangkok, Thailand; ${ }^{13}$ Premier \\ Clinical Research, Spokane, WA, USA; \\ ${ }^{14}$ Private Practice for Dermatology and \\ Aesthetics, Munich, Germany
}

Correspondence: Jani van Loghem Falck Clinic, Aesthetic Medicine Centre, Falckstraat 5I, Amsterdam, I0I7 VV, the Netherlands

Email jani@falckclinic.com
Background: As the treatment indications for the Cohesive Polydensified Matrix ${ }^{\circledR}$ hyaluronic acid (CPM-HA) portfolio continue to expand and diversify, injectors new to the range or those who are expanding the treatments they offer may be unsure of the optimal product and injection technique for specific facial areas. Each product in the CPM-HA portfolio has been intentionally designed to provide the best physical properties for a specific indication and target tissue. This document has been developed to provide a comprehensive, one-stop reference for clinicians using the portfolio.

Methods: An international panel of experts in the field of aesthetic medicine convened to develop guidelines on effective and safe injection technique when performing treatments with the CPM-HA range of soft-tissue fillers.

Results: Consensus members considered treatment indications in the upper, middle and lower face. Landmark deficiencies and anatomical considerations are described for each indication and consensus recommendations provided on the optimal product, injection depth and treatment technique. This is supplemented by the experts advice on avoidance of complications. Throughout, an evidence-based approach to selection of products and injection techniques is provided. The result is a fully tailored approach to a range of indications covering the full portfolio of CPM-HA products, including the newest addition for skin revitalization.

Conclusion: The recommendations in this consensus document are provided to assist clinicians in the selection of CPM-HA products, administration techniques and depths of injection with the aim of providing seamless and natural treatment results, enhanced safety and patient satisfaction.

Keywords: anatomy, Belotero, cohesive polydensified matrix, consensus, hyaluronic acid, injection technique

\section{Introduction}

Hyaluronic acid (HA) injections are one of the most common aesthetic procedures performed worldwide and an essential part of modern aesthetic practices. Unmodified HA has a half-life of only 24-48 hours in tissue, making it unsuitable for use as a dermal filler. However, synthetically cross-linking the HA improves stability, longevity, and viscoelastic properties. ${ }^{1}$ Several HA manufacturers have used proprietary crosslinking technologies to develop portfolios of HA fillers suitable for a variety of indications and injection depths. Cohesive polydensified matrix $\left(\mathrm{CPM}{ }^{\circledR}\right)$ is the crosslinking technology used for the broad and intentionally 
designed, diverse Belotero ${ }^{\circledR}$ HA range, ${ }^{2-4}$ which includes Soft (CPM-HA S, $20 \mathrm{mg} / \mathrm{mL}$ ), Balance (CPM-HA B, 22.5 $\mathrm{mg} / \mathrm{mL}$ ), Intense (CPM-HA I, $25.5 \mathrm{mg} / \mathrm{mL}$ ), Volume (CPM-HA V, $26 \mathrm{mg} / \mathrm{mL}$ ), Lips Contour (CPM-HA LC), Lips Shape (CPM-HA LS), and the most recent addition Belotero ${ }^{\circledR}$ Revive (CPM-HA R) (Table 1); with the exception of CPM-HA R, all are also available with lidocaine. The benefit of the portfolio offers the possibility to safely combine its products in order to tailor treatments to specific indications.

\section{Why is This Expert Consensus Required in Aesthetics?}

The variety of the available HA filler products requires injectors to be familiar with numerous fillers and know which product is optimal for a particular indication. The CPM-HA portfolio is one of the largest currently available on the market. Each product in the line has been intentionally designed to address a different spectrum of indications and injection depths, but injectors new to the range may be unsure of the optimal product and injection technique for specific facial areas. Furthermore, the safest injection layer and technique depends on the anatomy of the area. This expert panel was convened to provide recommendations on the most appropriate CPM-HA product, injection techniques and depths of injection for the more challenging facial aesthetic indications.

\section{Consensus Methodology}

The consensus statement draws on the combined expertise of 15 experts, including dermatologists, aesthetic clinicians, and an anatomist, with an average of 17.5 years of experience in aesthetic medicine and 8 years of experience with CPM-HA products. In April 2019, consensus members gathered for a full day meeting and were tasked with achieving "best practice in specific facial indications" based on local facial anatomy and individual product attributes. To facilitate the consensus process, the results of a pre-meeting questionnaire summarized the preferred product(s), injection volumes, depths and techniques of the group, and each member was responsible for presenting one facial area.

A consensus was defined as agreement from more than $75 \%$ of experts, with majority agreement denoted by agreement from $>50-75 \%$, consensus by $>75-95 \%$, and strong consensus by $>95 \%$. Statements are presented as recommended if they are supported by published clinical evidence or suggested if based on the experts' practical experience. All recommendations given here had a strong consensus unless otherwise indicated. For ease of use the recommendations for each facial area are also provided as a single file available as Supplementary Table 1.

\section{General Recommendations for Safe Injection Techniques and Avoidance of Complications}

Regardless of the technique and area of the face being treated sterile technique must be employed. Skin should be cleaned and disinfected and the areas re-treated if contaminated. The needle or cannula should be changed if no

Table I Properties of Cohesive Polydensified Matrix/Hyaluronic Acid Formulations. The Balance of Rheologic Properties in the CPMHA Range is Indicated by: - Absent, + Low, ++ Medium, +++ High, ++++ Very High

\begin{tabular}{|c|c|c|c|c|c|c|c|}
\hline & CPM-HA R & CPM-HA S & CPM-HA B & CPM-HA I & CPM-HA V & $\begin{array}{l}\text { CPM-HA } \\
\text { LC }\end{array}$ & CPM-HA LS \\
\hline $\begin{array}{l}\text { HA content/ } \\
\text { other active } \\
\text { ingredient }\end{array}$ & $\begin{array}{l}20 \mathrm{mg} / \mathrm{mL} \mathrm{HA} \text {; } \\
17.5 \mathrm{mg} / \mathrm{mL} \\
\text { glycerol }\end{array}$ & $\begin{array}{l}20 \mathrm{mg} / \mathrm{mL} \text { with/ } \\
\text { without } \\
\text { Lidocaine } 0.3 \%\end{array}$ & $\begin{array}{l}22.5 \mathrm{mg} / \mathrm{mL} \\
\text { with/without } \\
\text { Lidocaine } 0.3 \%\end{array}$ & $\begin{array}{l}25.5 \mathrm{mg} / \mathrm{mL} \\
\text { with/without } \\
\text { Lidocaine } 0.3 \%\end{array}$ & $\begin{array}{l}26 \mathrm{mg} / \mathrm{mL} \text { with/ } \\
\text { without } \\
\text { Lidocaine } 0.3 \%\end{array}$ & $\begin{array}{l}22.5 \mathrm{mg} / \mathrm{mL} \\
\text { Lidocaine } \\
0.3 \%\end{array}$ & $\begin{array}{l}25.5 \mathrm{mg} / \mathrm{mL} \\
\text { Lidocaine } 0.3 \%\end{array}$ \\
\hline Uses & $\begin{array}{l}\text { Skin } \\
\text { revitalizing }\end{array}$ & Superficial lines & $\begin{array}{l}\text { Medium to deep } \\
\text { lines; lip } \\
\text { enhancement }\end{array}$ & $\begin{array}{l}\text { Deep lines; } \\
\text { volume and lip } \\
\text { augmentation }\end{array}$ & $\begin{array}{l}\text { Improvement of } \\
\text { facial volume } \\
\text { loss }\end{array}$ & $\begin{array}{l}\text { Lip contour; } \\
\text { mild oral } \\
\text { commissures }\end{array}$ & $\begin{array}{l}\text { Lip volume; } \\
\text { severe oral } \\
\text { commissures }\end{array}$ \\
\hline Cohesivity & ++++ & ++++ & +++++ & +++++ & ++++ & +++++ & +++++ \\
\hline Elasticity & + & + & +++ & ++++ & +++++ & +++ & ++++ \\
\hline Viscosity & + & + & ++ & +++ & ++++ & ++ & +++ \\
\hline Plasticity & - & - & ++ & +++ & ++++ & ++ & +++ \\
\hline
\end{tabular}


longer sterile. Injections should not be performed through infected, inflamed or traumatized skin.

To reduce the risk of intravascular penetration, injections should be performed with low plunger pressure and in small aliquots. In addition, perpendicular (not parallel) orientation of the needle or cannula to the direction of the arteries is recommended. All injections should be performed with a moving needle as even if within a vessel, only minimal material will be deposited. The injector should advise the patient to inform him/her immediately if pain is felt during the procedure as this may be a sign of vessel penetration or ischemia. The injector should also focus on the needle tip to watch for blanching. Patients should be advised to return to the physician's practice immediately if they experience pain or bluish coloration in the first days after injection. Hyaluronidase should be available in every physician's office. Injecting with a blunt cannula of $25 \mathrm{G}$ or larger may further reduce the risk of an intravascular injection. ${ }^{5}$

\section{Upper Face Indications \\ Forehead}

\section{Landmark Deficiencies}

The aesthetic unit of the forehead is defined by the hairline superiorly, temporal crest laterally and the supraorbital rim inferiorly. ${ }^{6}$ Patients may seek aesthetic treatment for a number of forehead landmark deficiencies including suprabrow volume loss (frontal concavity), a prominent brow ridge, loss of forehead convexity, deep horizontal forehead lines, vertical glabellar lines, and diagonal sleeping lines; loss of temporal volume is considered in the section below. While botulinum toxin is effective at reducing glabellar and forehead lines, it will be less effective in foreheads that require volumetric augmentation and in subjects with visible wrinkles at rest. $^{7}$

The shape of the forehead is primarily determined by the shape of the underlying frontal bone, which loses its convexity with age. ${ }^{8}$ This may be combined with volume atrophy of the deep fat pads of the upper forehead, the middle and central forehead fat pads, retro-orbicularis oculi fat (ROOF), brow fat pads, and lateral temporal cheek fat pads. ${ }^{9}$ This deep and subcutaneous volume influences the shape of the forehead, brow position, surface smoothness of the forehead skin, and the type and configuration of forehead wrinkles (vertical and horizontal), all of which affect how old and attractive a person looks.

\section{Anatomical Considerations}

The arteries of interest in the forehead area are the supratrochlear and supraorbital arteries and their branches, as well as the frontal branch of the superficial temporal artery that connects to the supraorbital artery. ${ }^{9}$ The supratrochlear and supraorbital arteries travel upward under the frontalis muscle until approximately $1.5-2.0 \mathrm{~cm}$ above the orbital rim (a line correlating to the middle frontal septum $)^{9}$ when they pass through the muscle and become more superficial as they approach the hairline. In the upper forehead the arteries lie in a subcutaneous plane and if injecting in the supraperiosteal plane, three layers of tissue will separate the tip of the cannula from the arteries: fascia, fat and frontalis muscle. ${ }^{9}$

Some group members use sharp needles for forehead injections using 90 degrees for injections touching the bone, but no more than $0.025 \mathrm{~mL}$ of product should be injected per bolus or retrograde linear thread. This is based on information from a cadaver study which estimated that the average volume of the supratrochlear artery from the glabella to the orbital apex was only $0.085 \mathrm{~mL}$ with a spread to $0.04-0.12 \mathrm{~mL}$ in six cadavers. ${ }^{10}$ However, the consensus was that only blunt tip cannulas, at least $25 \mathrm{G}$ diameter, should be used for forehead augmentation.

\section{Product and Injection Technique}

Injections are placed in the supraperiosteal plane. The central entry point is in the midline at the top of the concavity (mind the facial vein when selecting the entry point). For the lateral forehead, recommended entry points are $1.5-2.0 \mathrm{~cm}$ above the orbital rim at the temporal crest, and if necessary, another lateral entry point higher towards the hairline at the temporal crest (Figure 1 and Table 2). Due to anatomical constraints, blunt tip cannulas (at least $22 \mathrm{G}$ ) are recommended.

Product choice will depend on factors such as the severity of the concavity and patient characteristics including skin thickness and degree of skin laxity. Treatment should therefore be tailored to the individual patient. Options include CPM-HA I, which has high projection capacity and does not deform easily, and CPM-HA V, which is easy to shape. In older patients with thin skin CPM-HA B may also be an option. CPM-HA I and CPMHA-V are injected with a $22 \mathrm{G}$ cannula with $0.025-0.04$ $\mathrm{mL} /$ thread, bevel directed towards the periosteum. It can be difficult to truly be in the supraperiosteal plane initially, and even when located in that space, it is possible to change planes easily, and injectors should ensure that the 


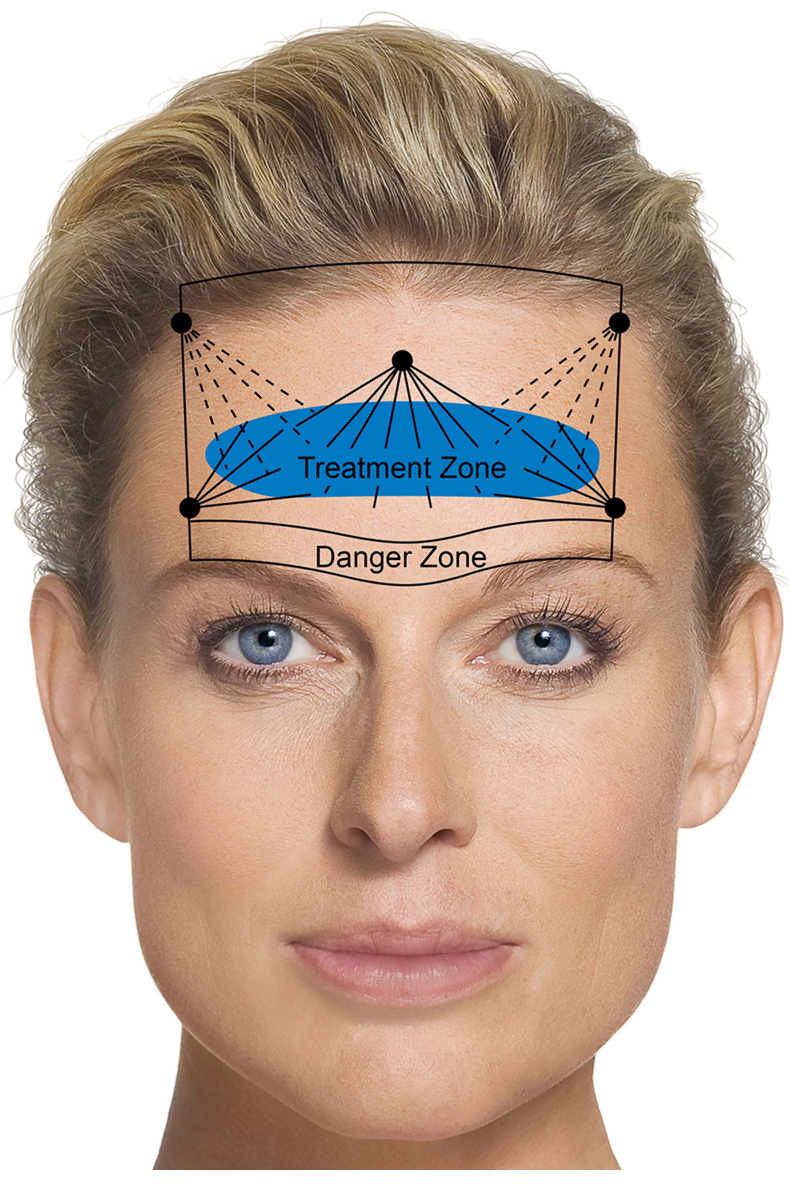

Figure I Forehead entry points and treatment zone. Black lines: limits of the forehead area (temporal crest, hairline, supraorbital rim) and limits of the arterial danger zone ( $1.5-2.0 \mathrm{~cm}$ superior to the supraorbital rim). Black dots: entry points. Lines from black dots: retrograde linear threads of $0.025-0.04 \mathrm{~mL}$ CPM-HA I or CPM-HA V with a 22G cannula, bevel directed towards the periosteum. Dotted black lines: optional additional retrograde linear threads. Image courtesy from Merz Pharmaceutical $\mathrm{GmbH}$.

cannula tip does not shift position during injection. Large boluses are not recommended when using CPM-HA I as the product is harder to mold after placement.

\section{Avoidance of Complications}

Injectors should not apply force and respect resistance by gently rotating the syringe from side to side to advance, instead of a forceful movement. Injections should be limited to small volume boluses or linear retrograde threads to avoid significant adverse outcomes, such as blindness, should inadvertent retrograde intra-arterial embolization occur. Injections with $30 \mathrm{G}$ or $31 \mathrm{G}$ needles are not advised when perpendicular on bone due to the possibility of intravascular injection in supraperiosteal or periosteal arteries. When injecting with thicker needles, the product will also distribute in more superficial anatomical layers along the injection canal due to backflow, even when using smaller injection angles. ${ }^{11}$ The consensus was that blunttipped cannulas are preferred for forehead augmentation as they reduce the risk of intravascular injection.

\section{Temples}

\section{Landmark Deficiencies}

The temple is an area of soft tissue between the temporal crest and the zygomatic arch. Loss of volume in this region may occur as a result of aging-associated changes in the underlying skeleton, redistribution of superficial and deep temporal fat pads, temporalis muscle atrophy, and skin laxity. ${ }^{12}$ Temporal volume loss is seen in conditions which cause facial lipoatrophy. In particular, HIV-infected individuals treated with highly active antiretroviral therapy have a typical skeletonized appearance to the face. Forehead shape is also affected by temple volume loss and vice versa.

\section{Anatomical Considerations}

When injecting in the temporal area it is important to be aware of anatomical landmarks to ensure correct entry points. In this region, arteries and veins are located in superficial layers of tissue as well as in the deeper layers. The superficial temporal artery, a branch of the external carotid artery, is located inside the superficial temporal fascia, and has connections to the supraorbital artery which is a branch of the ophthalmic artery. The anterior deep temporal artery anastomoses with the zygomaticotemporal artery, which connects likewise to the ophthalmic artery circulation. The middle zygomatico-temporal vein travels inside the superficial temporal fat pad and connects to the supraorbital vein in the supraperiosteal plane of the lower forehead.

\section{Product and Injection Technique}

Consensus members recommended dividing the temporal region into a posterior and anterior region (Figure 2 and Table 3), and into upper and lower temporal compartments separated by the inferior temporal septum. Unless the face appears very skeletonized, only the posterior temple is filled as this will also act to lift the middle and the lower face. ${ }^{13}$ For filler treatment, the posterior temple is divided into three zones, and injections in these different zones will result in different aesthetic effects (Figure 2). Injections in zone 1 will result in a lateral brow lift, injections in zone 2 will stretch the lower eyelid and lift the anterior temple, and injections in zone 3 will lift the 
Table 2 Recommendations for Forehead Augmentation and Rejuvenation

\begin{tabular}{|l|l|l|l|l|l|}
\hline Indication & $\begin{array}{l}\text { Product/ } \\
\text { Needle } \\
\text { or } \\
\text { Cannula } \\
\text { Size }\end{array}$ & Volume & $\begin{array}{l}\text { Injection } \\
\text { Plane }\end{array}$ & Technique & Avoidance of Complications \\
\hline $\begin{array}{l}\text { Medial } \\
\text { frontal } \\
\text { concavity }\end{array}$ & $\begin{array}{l}\text { CPM-HA } \\
\text { I or CPM- } \\
\text { HA V/ } \\
22 \mathrm{G} \\
\text { cannula }\end{array}$ & $\begin{array}{l}0.5 \mathrm{~mL} / \\
\text { side; } \\
0.025- \\
0.04 \mathrm{~mL} / \\
\text { thread }\end{array}$ & Subgaleal & $\begin{array}{l}\text { Central entry point just at the top of frontal } \\
\text { eminence below hairline. Remember to } \\
\text { palpate for superior temporal artery and } \\
\text { look for facial vein in this area }\end{array}$ & $\begin{array}{l}\text { Do not apply force, gently rotate syringe } \\
\text { from side to side to advance. Use small } \\
\text { volume boluses or linear retrograde } \\
\text { threads. Blunt-tipped cannulas preferred for } \\
\text { forehead augmentation }\end{array}$ \\
\hline $\begin{array}{l}\text { Lateral } \\
\text { frontal } \\
\text { concavity }\end{array}$ & $\begin{array}{l}\text { CPM-HA } \\
\text { I or CPM- } \\
\text { HA V 22G } \\
\text { cannula }\end{array}$ & $\begin{array}{l}0.5-1.0 \\
\mathrm{~mL} / \mathrm{side} \\
0.025- \\
0.04 \mathrm{~mL} / \\
\text { thread }\end{array}$ & Subgaleal & $\begin{array}{l}\text { Lateral entry points are I.5-2.0 cm above } \\
\text { the orbital rim at the temporal crest; } \\
\text { optional additional entry point higher } \\
\text { towards hairline. With lateral entry points } \\
\text { product should be injected in a direction } \\
\text { perpendicular to arteries }\end{array}$ & \\
\hline
\end{tabular}

Note: Level of consensus: Strong.

lateral cheek and provide mandibular definition. ${ }^{14}$ Injections in all three posterior temple zones are performed with a cannula. The use of assessment scales such as the Merz validated temple scale is helpful to grade severity. For moderate to severe superficial fat loss experts recommended CPM-HA V or CPM-HA I $0.5-1.0 \mathrm{~mL} / \mathrm{side}$ with a $22 \mathrm{G}$ cannula injected subdermally (for volume and lifting) or in the interfascial space (for volume replacement only); higher volumes can be used in more severe cases (Figure 3). If the anterior temple needs volumizing, the injection should be performed with CPM-HA V at the periosteal or interfascial level, or a very small amount in the subdermal level. In order to correct volume deficiency with epiperiosteal injection, significantly more product will be necessary. ${ }^{15}$ Injections with a needle should not be performed in the lower temporal compartment due to

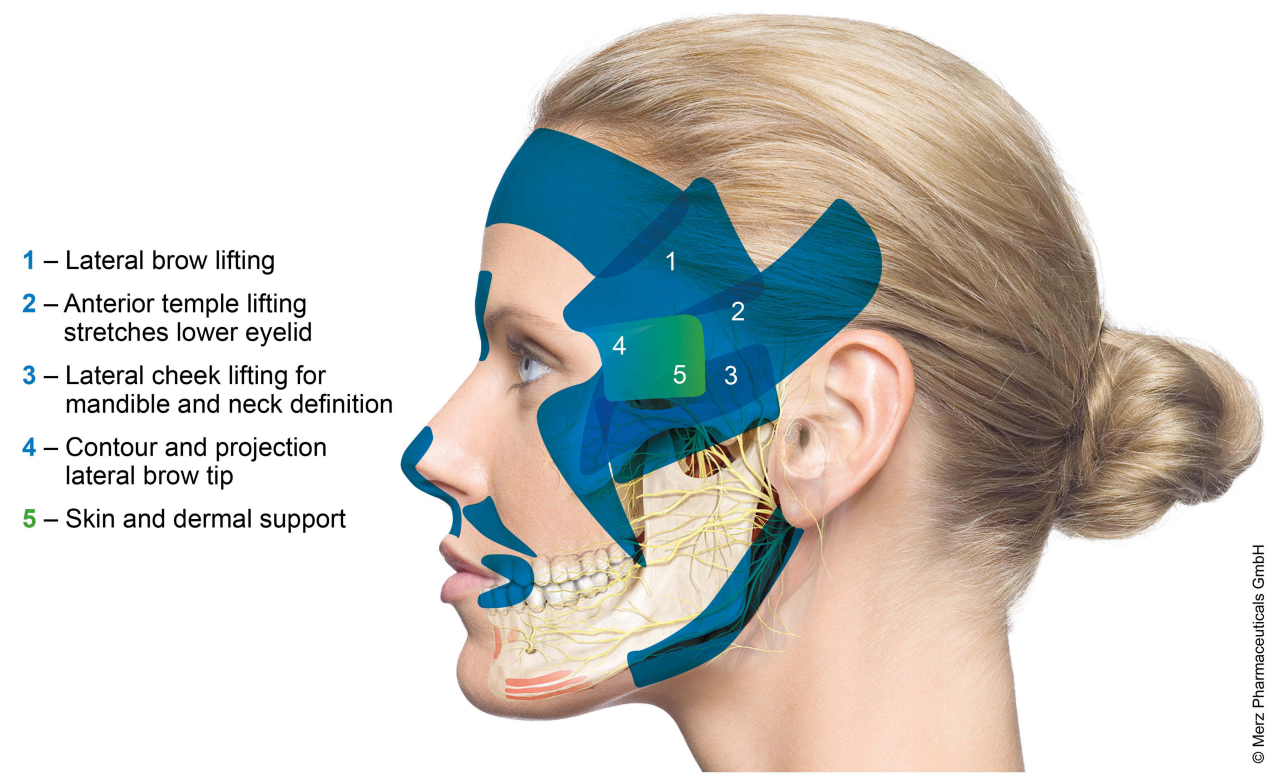

Figure 2 Treatment of the temples. The posterior temple is divided into three zones (I-3), and injections in these different zones will result in different aesthetic effects. Injection in the anterior temple (zone 4 ) is only required for very skeletonized faces. ${ }^{14}$ Zone 5 covers the same area as zone 4 , but signifies smoothing of transitions in the area. Image courtesy from Merz Pharmaceutical GmbH. 
Table 3 Recommendations for Temple Contouring

\begin{tabular}{|c|c|c|c|c|c|}
\hline Indication & $\begin{array}{l}\text { Product/ } \\
\text { Needle } \\
\text { or } \\
\text { Cannula } \\
\text { Size }\end{array}$ & Volume & $\begin{array}{l}\text { Injection } \\
\text { Plane }\end{array}$ & Technique & Avoidance of Complications \\
\hline $\begin{array}{l}\text { Posterior and } \\
\text { anterior temples } \\
\text { volume loss }\end{array}$ & $\begin{array}{l}\text { CPM-HA } \\
\text { I or CPM- } \\
\text { HA V/ } \\
22 \text { G stiff } \\
\text { cannula }\end{array}$ & $\begin{array}{l}0.5-1.0 \mathrm{~mL} / \mathrm{side} \\
\text { higher volumes may } \\
\text { be required if } \\
\text { volume loss severe; } \\
0.05-0.1 \mathrm{~mL} / \text { thread }\end{array}$ & $\begin{array}{l}\text { Subdermal or } \\
\text { Interfascial }\end{array}$ & $\begin{array}{l}\text { Temporal crest entry point, from } \\
\text { frontal periosteum through } \\
\text { temporal crest into the } \\
\text { interfascial space. Multiple passes } \\
\text { injecting small amounts. } \\
\text { Zygomatic arch entry point, } \\
\text { staying strictly hypodermal, } \\
\text { multiple passes hairline and } \\
\text { upwards injecting tiny threads } \\
\text { (only CPM-HA V). }\end{array}$ & \multirow[t]{3}{*}{$\begin{array}{l}\text { A negative aspiration test result } \\
\text { is not conclusive. Temple } \\
\text { injections should be performed } \\
\text { with a } 22 \mathrm{G} \text { blunt-tipped cannula } \\
\text { and performed very slowly }\end{array}$} \\
\hline $\begin{array}{l}\text { Posterior and } \\
\text { anterior temples } \\
\text { visible temporal } \\
\text { blood vessels and } \\
\text { very thin skin }\end{array}$ & $\begin{array}{l}\text { CPM-HA } \\
\text { B/22 G } \\
\text { stiff } \\
\text { cannula }\end{array}$ & $\begin{array}{l}0.5-1.0 \mathrm{~mL} / \text { side; } \\
0.05 \mathrm{~mL} / \text { thread }\end{array}$ & Subdermal & $\begin{array}{l}\text { Temporal crest entry point. } \\
\text { Multiple passes injecting small } \\
\text { amounts. } \\
\text { Zygomatic arch entry point, } \\
\text { staying strictly hypodermal, } \\
\text { multiple passes hairline and } \\
\text { upwards injecting tiny threads. }\end{array}$ & \\
\hline $\begin{array}{l}\text { Severe anterior } \\
\text { temples volume } \\
\text { loss }\end{array}$ & $\begin{array}{l}\text { CPM-HA } \\
\text { V/27G or } \\
30 \mathrm{G} \\
\text { needle }\end{array}$ & $\begin{array}{l}\text { Max } 0.1 \mathrm{~mL} / \text { bolus, } \\
0.5-1.0 \mathrm{~mL} / \mathrm{side}\end{array}$ & Supraperiosteal & Microbolus. & \\
\hline
\end{tabular}

Note: Level of consensus: Strong.

the presence of the deep temporal arteries and the connection of the deep temporal fat compartment with the Bichat fat of the cheek.

Certain patients may present with visible blood vessels in the temporal area. Treatment should be individualized based on skin properties. In patients with very thin skin, the consensus approach for treatment was to use CPM-HA $\mathrm{B}$, which has low elasticity and viscosity as well as high cohesivity for seamless and natural tissue integration. Using a temporal crest entry point, the product is injected subdermally with a $22-25 \mathrm{G}$ cannula ( $22 \mathrm{G}$ is preferred for safety reasons, but as the diameter is larger the product will flow more easily and more will be used per strand). A retrograde, linear threading technique is used, injecting small amounts in multiple passes for a total volume of $0.5-1.0 \mathrm{~mL} / \mathrm{side}$. CPM-HA V is preferred for normal and thicker skin as much less product is required. Consensus was that a cannula $(22-25 \mathrm{G})$ is preferred to perform injections in the temporal region.
Certain experts use a sandwich technique when correcting very severe volume loss in the posterior temple, injecting CPM-HA V for both lifting and contouring due to its high elasticity and plasticity, but no studies have been conducted using this combination approach and further research is required.

\section{Avoidance of Complications}

Anastomoses of the superficial temporal artery with the supraorbital and supratrochlear arteries and of the anterior deep temporal artery with the lacrimal artery present a risk of blindness should artery embolization occur. The use of aspiration as a method of avoiding vascular complications is highly controversial. Opinion is mainly driven by personal experience, and experts were divided approximately 50:50 on whether it should be recommended, as certain experts felt it would give a false sense of security. ${ }^{16}$ The high viscosity of certain fillers, for example CPM-HA V and CPM-HA I, may give unreliable aspiration results if using a $27 \mathrm{G}, 13 \mathrm{~mm}$ 

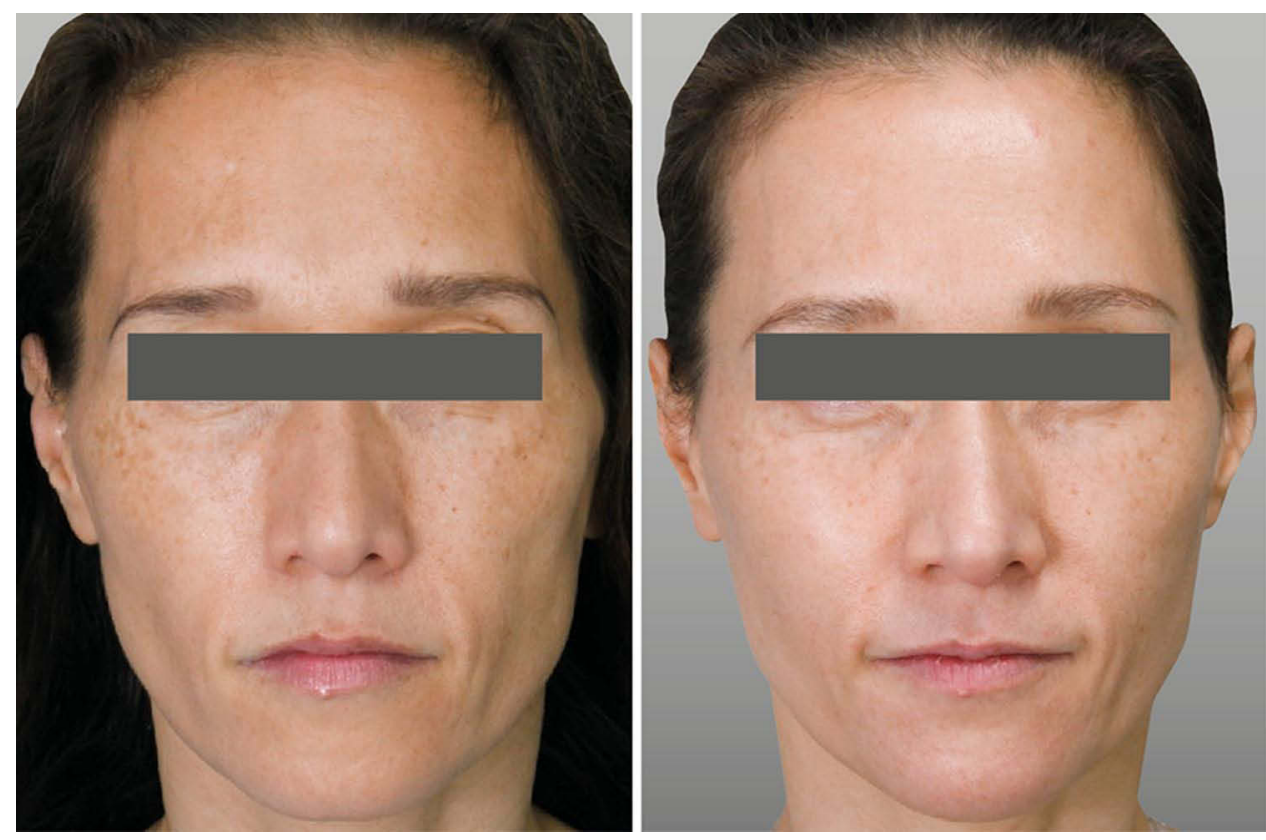

Figure 3 Before and after I mL CPM-HA V to the temples (other indications were treated too). Courtesy Jani van Loghem, MD.

needle, as a high suction pressure and long aspiration time (up to $8 \mathrm{~s}$ ) may be required to obtain a positive test result. ${ }^{17}$ A negative test result (no blood in needle hub) should therefore not be relied on due to the high probability of a false negative result. Injections in this area should be performed with a $22 \mathrm{G}$ blunt-tipped cannula and performed very slowly, so patients can comment on how they feel.

\section{Superior Orbital Hollowness Landmark Deficiencies}

As the orbit widens during aging, the eyes will start to look hollower, often accentuated by intraorbital fat loss. ${ }^{18}$ Superior orbital hollowness also known as A-frame deformity or sunken upper eyelid sulcus may be genetic or associated with aging as a result of atrophy of preseptal fat in the upper eyelid. ${ }^{18}$ Patients with severe hollowing have very thin upper eyelid skin and little or no subcutaneous fat. The resulting hollowness of the upper eyelid makes individuals look older than their biological age.

\section{Anatomical Considerations}

In the superior orbital area, vessels to be aware of include the supratrochlear artery, which passes below the superior orbital rim in the supratrochlear notch, the supraorbital artery that exits through the supraorbital foramen, and more medially, the angular and dorsal nasal arteries.

\section{Product and Injection Technique}

Prior to injection, the upper eyelid crease and the supraorbital rim should be marked as this is the area that should be filled (Figure 4). No product should be injected below the upper eyelid crease (Figure 4). A preinsertion point is made with a $23 \mathrm{G}$ needle on the lateral superior orbital rim. CPM-HA B is the preferred product as it has a low viscosity and a low G prime and therefore shows seamless tissue integration, low hygroscopy, no discoloration and no Tyndall effect. ${ }^{19}$ Using a $25 \mathrm{G}$ cannula, CPM-HA B $(0.3-0.5 \mathrm{~mL} / \mathrm{side})$ is placed just deep to the orbicularis oculi muscle in the preseptal fat and superficial to the orbital septum, but not deeper (Table 4). Very small amounts of product are placed per injection $(\max 0.025 \mathrm{~mL})$ as it is impossible to massage this area. The tip of the cannula should not be visible during the injection as this would indicate product is being placed subdermally and not in the preseptal fat, which will make the lid heavier. In patients with severe hollowing, small amounts of CPM-HA I may be used because of its lifting effect. CPM-HA $\mathrm{S}$ injected subcutaneously may be appropriate for less severe cases but is not ideal to replace lost volume.

Consensus members advised that HA fillers were the best option to address volume deficiency, but if the hollowing results from excess upper eyelid laxity, skin 


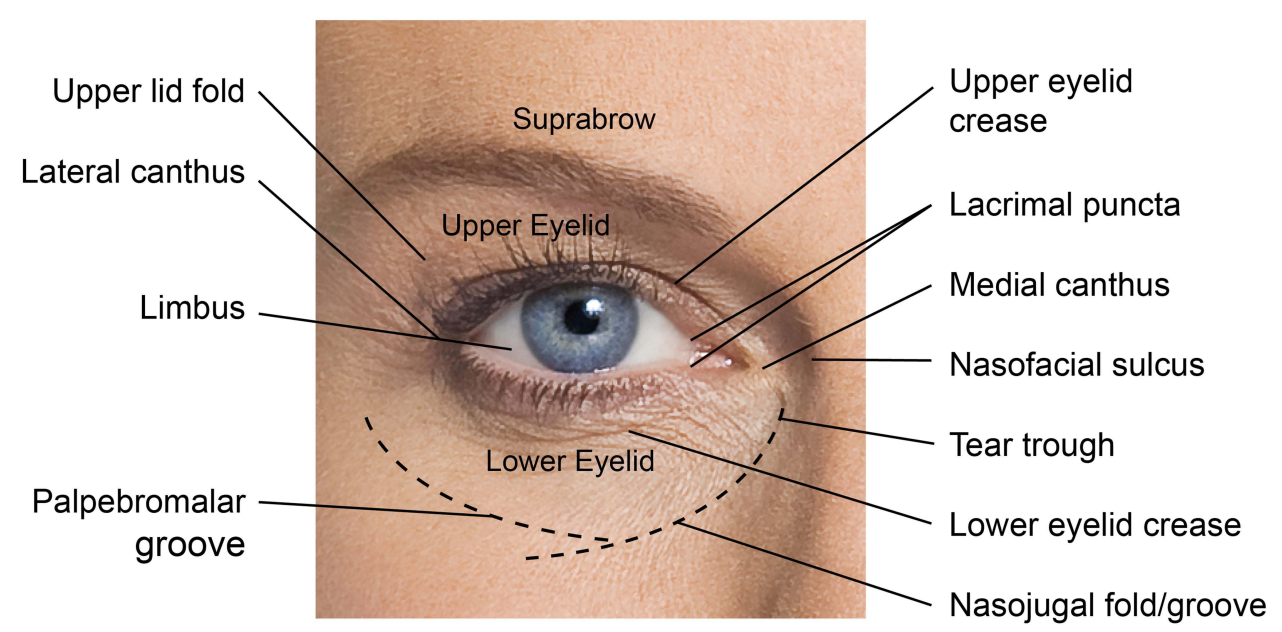

Figure 4 Periorbital landmarks.

tightening procedures such as a fully ablative $\mathrm{CO}_{2}$, fractionated $\mathrm{CO}_{2}$ or microfocused ultrasound with visualization (MFU-V) are indicated either alone or followed by HA filler.

\section{Avoidance of Complications}

Injectors should avoid injecting too close to the supraorbital foramen because of the risk of injecting the neurovascular bundle, which sometimes has a connection to the upper eyelid. Depending on the amount of product injected, there can be temporary swelling as HA is hygroscopic and therefore undertreatment is advised (80\% correction in severe cases where up to $0.5 \mathrm{~mL}$ CPM-HA B per side is injected and $90 \%$ correction in mild cases where up to $0.3 \mathrm{~mL}$ per side is injected). Follow-up treatment if necessary may be performed when swelling has subsided.

\section{Mid Face Indications}

\section{Infraorbital Hollows}

\section{Landmark Deficiencies}

The infraorbital region can present with hollowing. However, depending on where the aesthetically unpleasing depression is located it is termed differently. Medial to the mid-pupillary line, the depression is termed tear trough. Lateral to the mid-pupillary line, it is termed palpebromalar groove. The $\mathrm{V}$-frame deformity refers to the area located between these two deformities and is associated with midfacial soft tissue descent. The nasojugal groove refers to the inferior end of the tear trough which is formed by the superior margin of the superficial nasolabial fat compartment (Figure 4). ${ }^{20}$ With thin skin overlying bone and little to no subcutaneous fat or muscle in this region, the infraorbital region can be a challenging region to treat due to a variety of factors: herniation of intraorbital fat,

Table 4 Recommendations for Superior Orbital Hollowness

\begin{tabular}{|l|l|l|l|l|l|}
\hline Indication & $\begin{array}{l}\text { Product/ } \\
\text { Needle } \\
\text { or } \\
\text { Cannula } \\
\text { Size }\end{array}$ & Volume & Injection Plane & Technique & $\begin{array}{l}\text { Avoidance of } \\
\text { Complications }\end{array}$ \\
\hline $\begin{array}{l}\text { Superior } \\
\text { orbital } \\
\text { hollowness }\end{array}$ & $\begin{array}{l}\text { CPM-HA } \\
\text { B/25G } \\
\text { cannula }\end{array}$ & $\begin{array}{l}0.3-0.5 \mathrm{~mL} / \text { side } \\
(0.025 \mathrm{~mL} / \text { droplet })\end{array}$ & $\begin{array}{l}\text { Deep to the orbicularis } \\
\text { oculi muscle in the } \\
\text { preseptal fat and above } \\
\text { the levator aponeurosis }\end{array}$ & $\begin{array}{l}\text { Preinsertion point made with 23G } \\
\text { needle on the lateral superior orbital } \\
\text { rim. CPM-HA I may be used for severe } \\
\text { hollowing and CPM-HA S for mild } \\
\text { hollowing. Undertreatment advised }\end{array}$ & $\begin{array}{l}\text { Avoid injecting too } \\
\text { close to supraorbital } \\
\text { foramen. } \\
\text { Undercorrection } \\
\text { advised for this } \\
\text { indication }\end{array}$ \\
\hline
\end{tabular}

Note: Level of consensus: Strong. 
Table 5 Recommendations for Infraorbital Hollows

\begin{tabular}{|c|c|c|c|c|c|}
\hline Indication & $\begin{array}{l}\text { Product/Needle } \\
\text { or Cannula Size }\end{array}$ & Volume & Injection Plane & Technique & $\begin{array}{l}\text { Avoidance of } \\
\text { Complications }\end{array}$ \\
\hline $\begin{array}{l}\text { Stage I } \\
\text { Zygomatic cutaneous } \\
\text { (ZCL) and zygomatic } \\
\text { retaining ligaments } \\
\text { (ZRL) lifting or cheek } \\
\text { augmentation }\end{array}$ & $\begin{array}{l}\text { CPM-HA I or CPM- } \\
\text { HA V/22-25G } \\
\text { cannula }\end{array}$ & $\begin{array}{l}0.5 \mathrm{~mL} / \mathrm{side} ; \\
0.05-0.1 \mathrm{~mL} / \\
\text { bolus }\end{array}$ & $\begin{array}{l}\text { Periosteal at the } \\
\text { origin of the } Z R L \\
\text { and } Z C L \text {, at the } \\
\text { periosteum of the } \\
\text { zygoma }\end{array}$ & $\begin{array}{l}\text { Injection below zygomatic } \\
\text { cutaneous and zygomatic retaining } \\
\text { ligaments to reposition them more } \\
\text { horizontally, or periosteal cheek } \\
\text { augmentation }\end{array}$ & \multirow{3}{*}{$\begin{array}{l}\text { SOOF injections } \\
\text { should be } \\
\text { periosteal to } \\
\text { avoid malar } \\
\text { edema. } \\
\text { Undercorrection } \\
\text { advised when } \\
\text { treating } \\
\text { infraorbital } \\
\text { hollows }\end{array}$} \\
\hline $\begin{array}{l}\text { Stage } 2 \\
\text { Palpebromalar groove }\end{array}$ & $\begin{array}{l}\text { CPM-HA B/23-25G } \\
\text { cannula. Certain } \\
\text { experts } \\
\text { recommended } \\
\text { CPM-HA I or CPM- } \\
\mathrm{HA} \mathrm{V}^{\dagger}\end{array}$ & $\begin{array}{l}0.2-0.5 \mathrm{~mL} / \\
\text { side; } 0.025- \\
0.05 \mathrm{~mL} / \text { thread }\end{array}$ & Periosteal & $\begin{array}{l}\text { Target palpebromalar groove } \\
\text { inferior to the orbicularis retaining } \\
\text { ligament. Insertion point lateral to } \\
\text { orbicularis oculi muscle skin } \\
\text { insertion or using the same } \\
\text { insertion point as for the tear } \\
\text { trough, place small amount of } \\
\text { product below lateral orbital } \\
\text { thickening }\end{array}$ & \\
\hline $\begin{array}{l}\text { Stage } 3 \\
\text { Tear trough }\end{array}$ & $\begin{array}{l}\text { CPM-HA B/25G } \\
\text { cannula. Some } \\
\text { recommended } \\
\text { CPM-HA S }\end{array}$ & $\begin{array}{l}0.1-0.5 \mathrm{~mL} / \\
\text { side; } 0.025- \\
0.05 \mathrm{~mL} / \\
\text { thread. } \\
\text { Max } 0.1 \mathrm{~mL} / \\
\text { side of CPM- } \\
\text { HA S if } \\
\text { injected } \\
\text { subcutaneously }\end{array}$ & $\begin{array}{l}\text { Periosteal (CPM- } \\
\text { HA B) } \\
\text { Subcutaneous } \\
\text { (CPM-HA S) }\end{array}$ & $\begin{array}{l}\text { Injections are placed deep on the } \\
\text { periosteum between the ORL and } \\
\text { zygomatic cutaneous ligament } \\
\text { taking care to stay below malar } \\
\text { septum and only inject small } \\
\text { amounts }\end{array}$ & \\
\hline
\end{tabular}

Note: Level of consensus: Strong. ${ }^{\dagger}$ Recommended by 3 experts + I for CPM-V.

atrophy of the skin and subcutaneous fat, contraction of the orbital part of the orbicularis oculi muscle, and malar bone resorption. ${ }^{20}$ It is also accentuated by descent of the mid-cheek.

\section{Anatomical Considerations}

Recent anatomical studies indicate that the lower eyelid and lid-cheek junction should be regarded as a single unit and influence each other during aging. ${ }^{21}$ In the lateral lower eyelid, a thin layer of subcutaneous fat can be observed, which is absent in the medial part of the lower eye lid, ie the tear trough. ${ }^{21}$ Malar edema is a frequent complication of the lateral infraorbital area and occurs when HA filler is trapped between the malar septum and the skin. ${ }^{22}$ Lymphatic drainage vessels become blocked, lymphatic fluid accumulates, and the increasing hydrostatic pressure results in malar mounds. Certain patients may already have impaired lymphatic drainage and should be treated with care or in combination with other treatment modalities.

\section{Product and Injection Technique}

Treatment of the infraorbital hollow can be approached in three stages (Table 5). The first stage targets the zygomatic cutaneous and zygomatic retaining ligaments by injecting a small amount of product below the ligaments into the SOOF to orient them more horizontally, essentially lifting the cheek (Figure 5). The second stage focuses on the palpebromalar groove (also known as the lid-cheek crease) by targeting the circular orbicularis retaining ligament (ORL). The ORL has its origin at the orbital rim and inserts into the orbicularis oculi muscle that is attached to the skin. With age, the orbit widens due to bone resorption and the ORL descends. Placement of filler product just below the ORL on the periosteum can push the ORL into a more horizontal orientation and therefore reduce the palpebromalar groove created by the ORL insertion. It also has the added advantage of lifting the corner of the eye. The choice of product depends on patient characteristics including volume deficit and skin thickness. CPM-HA I or CPM-HA V may be a good option for patients with thicker 


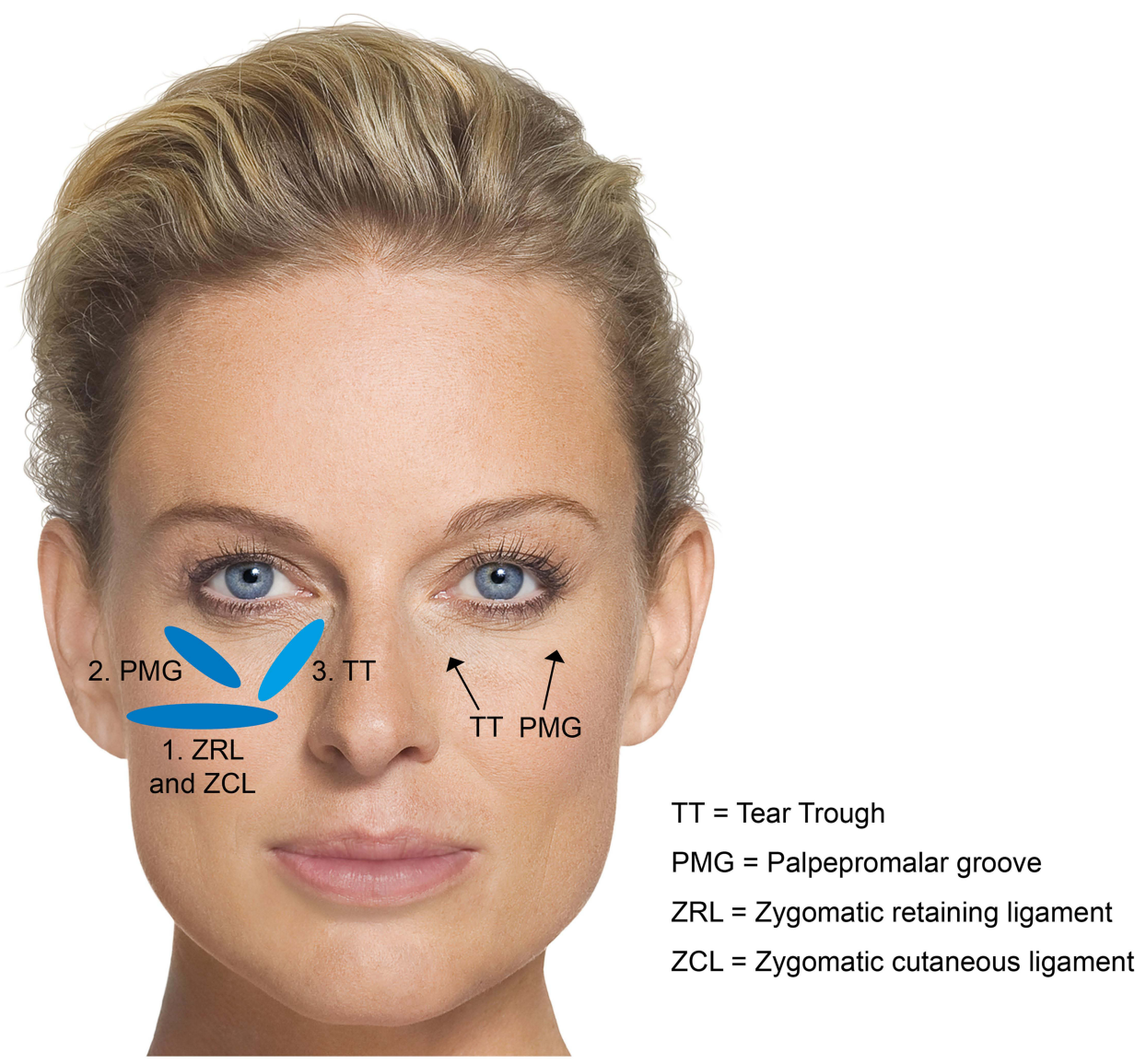

Figure 5 Treatment of the infraorbital hollows. Image courtesy from Merz Pharmaceutical GmbH.

skin, but in patients with thin skin, CPM-HA B is the preferred product due to its low elasticity and viscosity and high cohesivity which provide seamless and natural tissue integration properties. CPM-HA B is injected with a $22-25 \mathrm{G}$ cannula as close to the retaining ligament as possible from an insertion point lateral to the orbicularis oculi skin insertion (Figure 6). Another option is to choose the same insertion point as for the tear trough close to the midline, just laterally from the angular vein, with the cannula directed towards the lateral epicanthus. Thereby, a small amount of product can be placed below the lateral orbital thickening to increase the lateral lifting vector. The size of the cannula and injection plane remain the same (see above). In patients with very thin skin, CPM-HA S may be used to disguise dark shadows.

The third stage of treatment targets the tear trough, which is located between the ORL and the nasojugal groove. The tear trough is treated by placing CPM-HA at the supraperiosteal level in between the tear trough ligament and the angular vein, going as far medially as the anatomy allows. At this point there is an attachment of the tear trough ligament to the bone prohibiting further advancement and the cannula is advanced more superficially in the subdermal layer to reach the medial part of the tear trough. The consensus was for CPM-HA B (due to its ability to provide seamless and natural integration in this very delicate area) injected with a $25 \mathrm{G}$ cannula or larger. When injecting the tear trough, it is important to stay deep on the periosteum and only inject small amounts of product totalling $0.1-0.5 \mathrm{~mL} / \mathrm{side}$. Some consensus members also recommended injecting with CPM-HA $\mathrm{S}$ in the subcutaneous layer.

The treatment of the IOH may be performed in two sessions, the first covering the palpebromalar groove, and the second the tear trough.

\section{Avoidance of Complications}

To avoid malar edema, injections in the SOOF should always be placed periosteally. ${ }^{22}$ Patient selection is key. Patients should be asked if they wake up with swollen eyelids in the morning; if so, they are not suitable 

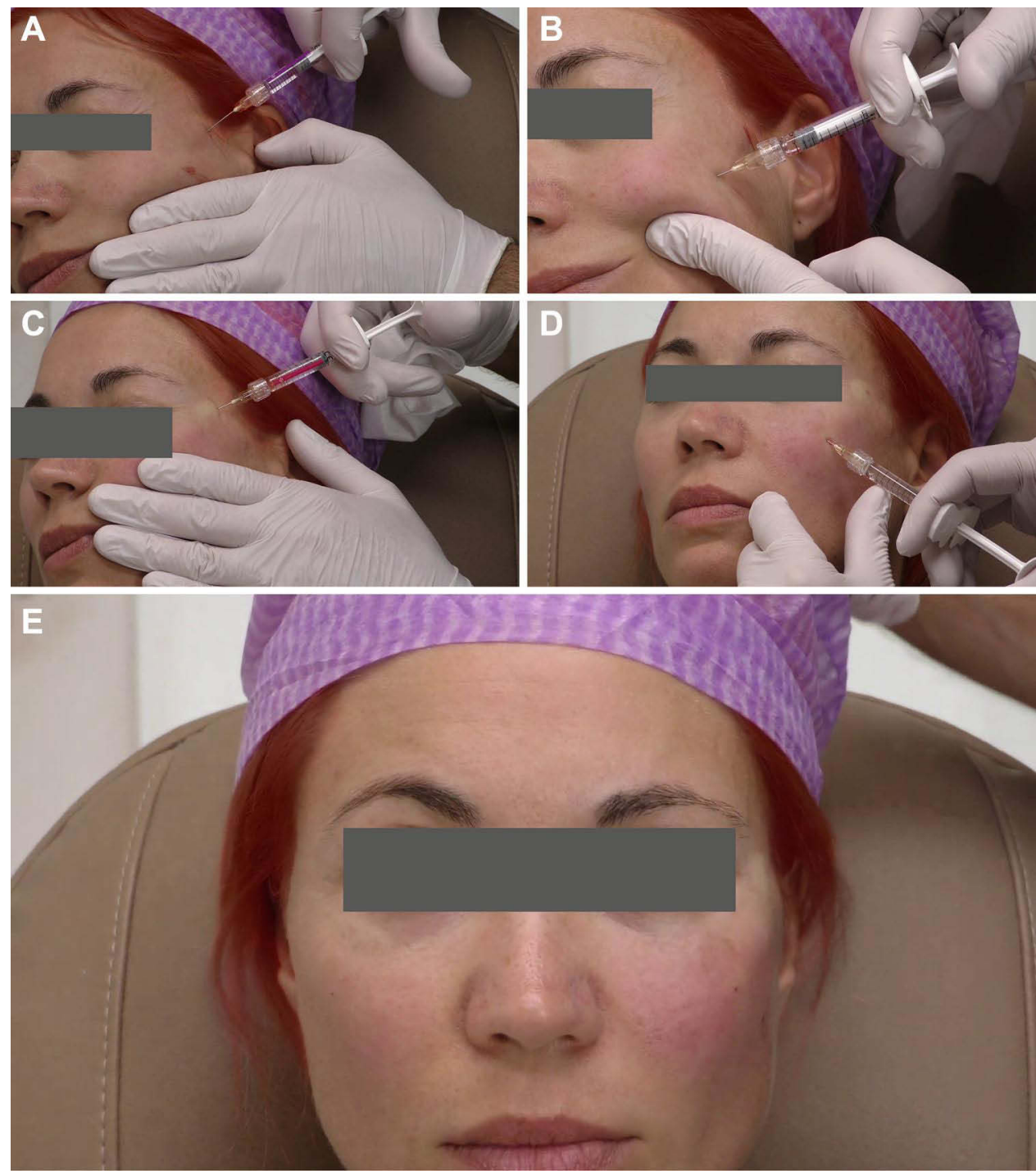

Figure 6 Clinical photo series of three stages of IOH treatment. Courtesy Jani van Loghem, MD. (A) Lateral Cheek (CPM-HA V); (B) Medial Cheek (CPM-HA V); (C) Palpebromalar groove (CPM-HA I); (D) Tear trough (CPM-HA B); (E) Result immediately after left side treated. Note the canthal tilt improvement.

candidates for this procedure because of an increased risk of malar edema, which is difficult to resolve. Always undercorrect by up to $10-20 \%$. Patients with moderate and severe skin laxity ("positive pinch test") or fat herniation should be treated with other suitable modalities; filler injections must be avoided in these patients.

\section{Pre-Auricular Hollowing} Landmark Deficiencies

Pre-auricular hollowing is the area anterior to the ears and has as superior boundary the zygomatic arch (diagonal cheekbones in women, more horizontal in men), and as inferior boundary the jawline (Figure 7). It is an important aesthetic landmark and an outward statement of health and sexual dimorphism. Pre-auricular flattening or loss of concavity may also occur post-facelift. The area of shadow differs in men and women and is typically ovoid in women and triangular to square shape in men.

When treating this area there are therefore two objectives: to create shadow with cheek augmentation and to correct excessive hollowing and wrinkles when there is age-related volume loss.

\section{Anatomical Considerations}

This area is not a particular danger zone for subcutaneous or subdermal injections, but deeper injections may enter the parotid gland, Stenson's duct and various veins which course over the masseter. Arteries in this area also run deep and include the external carotid artery, transverse facial artery, and maxillary artery, as do the facial nerve and its branches. 


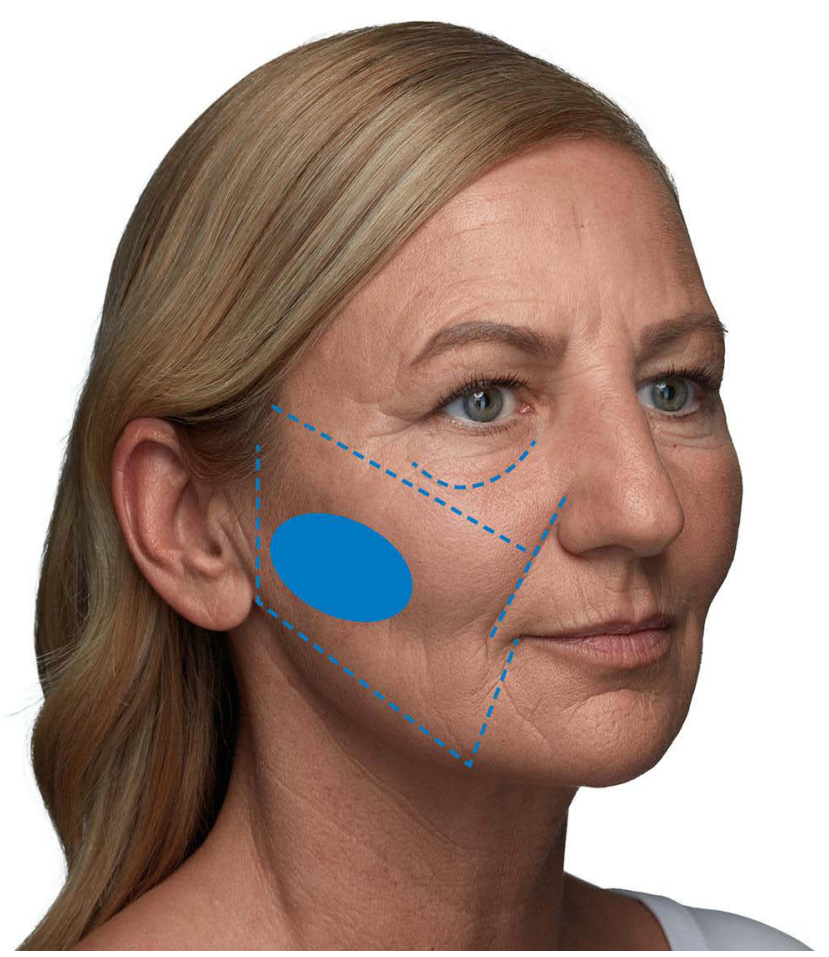

Figure 7 Pre-auricular hollowing: landmark deficiencies illustrating midface borders. The mid cheek ideally has a small concavity, resulting in a low light "shadow" from the zygoma above. In women, this concavity classically has an ovoid shape. In men, the shape tends to be more square or rectangular. Image courtesy from Merz Pharmaceutical GmbH.

\section{Product and Injection Technique}

For volumization of the hollow, all experts recommended CPM-HA V due to its high elasticity and viscosity. The product should be molded to the desired shape immediately post injection and to ensure a smooth transition between the treated and untreated areas. CPM-HA V is injected with a $22 \mathrm{G}$ or $25 \mathrm{G}$ cannula subdermal with a retrograde fanning technique (Table 6). The aim is to correct the depression, but not to create convexity.

To create pre-auricular hollowing a vectoring approach is used to augment and lift across the zygoma taking care to create a more ovoid hollowing in women and more geometric (sharper defined) hollowing in men (Figure 8).

\section{Avoidance of Complications}

In addition to deep vessels such as the transverse facial artery, a branch of the superficial temporal artery, the parotid gland lies below the subcutaneous fat, deep to the injection plane, and should be avoided as intraglandular injection can result in parotitis. In the medial portion, care should be taken to avoid the facial vein.

\section{Radial Cheek Lines Landmark Deficiencies}

Static radial cheek lines occur with aging as a result of soft tissue migration, bone resorption, fat atrophy of the buccal and lateral cheek fat pads and laxity of the fat pad boundaries, loss of skin elasticity, and SMAS contraction. ${ }^{23}$ The different deficiencies lead to three different classes of radial cheek lines. Type 1 lines are due to structural deficiencies related to bone resorption and atrophy and redistribution of the fat pads (Figure 9A). Type 2 lines are due to skin laxity resulting from a loss of collagen and elastin as a result of extrinsic and intrinsic skin aging (Figure 9B). Finally, type 3 lines are due to a combination of the above (Figure 9C). It is important to analyze the patient carefully to determine the underlying cause as the different deficiencies require individual treatment approaches.

\section{Anatomical Considerations}

Radial cheek lines are lines ingrained into the face at rest by habitual expressions. An etiological understanding of fine lines provides the rationale for addressing them with HA fillers. Age-related volume loss occurs at multiple levels, involving bone, subcutis, dermis and epidermis, it is therefore important to assess the patient for their need for layered volumization.

Recent anatomical studies have described the boundaries of the superficial and deep fat compartments and demonstrated that they behave differently on injection of filler material. ${ }^{24}$ For example, whereas the inferior aspect of the middle cheek fat compartment descended on filling, this was not observed for the superficial medial cheek (malar fat) compartment, lateral cheek, and both superficial

Table 6 Recommendations for Pre-Auricular Hollowing

\begin{tabular}{|l|l|l|l|l|l|}
\hline Indication & $\begin{array}{l}\text { Product/Needle } \\
\text { or Cannula Size }\end{array}$ & Volume & $\begin{array}{l}\text { Injection } \\
\text { Plane }\end{array}$ & Technique & $\begin{array}{l}\text { Avoidance of } \\
\text { Complications }\end{array}$ \\
\hline $\begin{array}{l}\text { Pre-auricular } \\
\text { hollowing }\end{array}$ & $\begin{array}{l}\text { CPM-HA V/22- } \\
25 G \text { cannula }\end{array}$ & $\begin{array}{l}0.1-0.5 \mathrm{~mL} / \mathrm{side} ; \\
0.05-0.1 \mathrm{~mL} / \\
\text { thread }\end{array}$ & Subdermal & $\begin{array}{l}\text { Retrograde fanning technique } \\
\text { using a vectoring approach. }\end{array}$ & $\begin{array}{l}\text { Avoid transverse facial artery, } \\
\text { parotid gland and facial vein }\end{array}$ \\
\hline
\end{tabular}

Note: Level of consensus: Strong. 

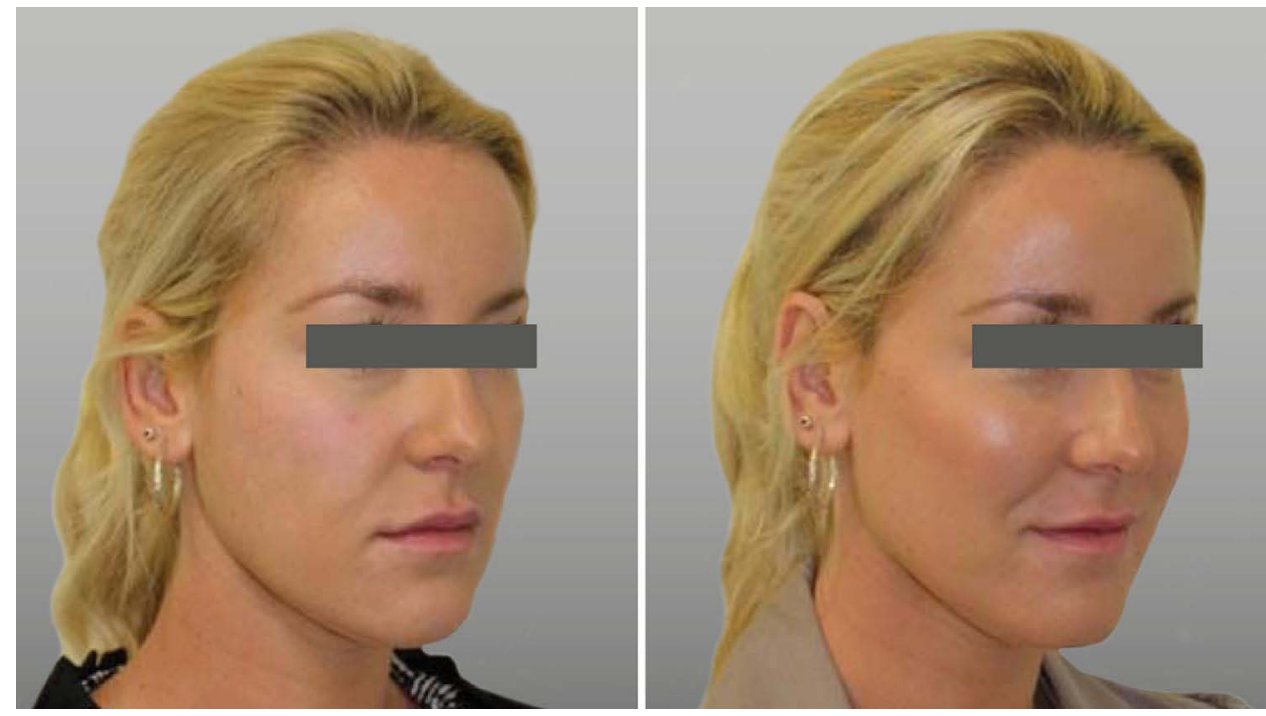

Figure 8 Addressing mid-face hollowing. Courtesy of W. Philip Werschler, MD.

A

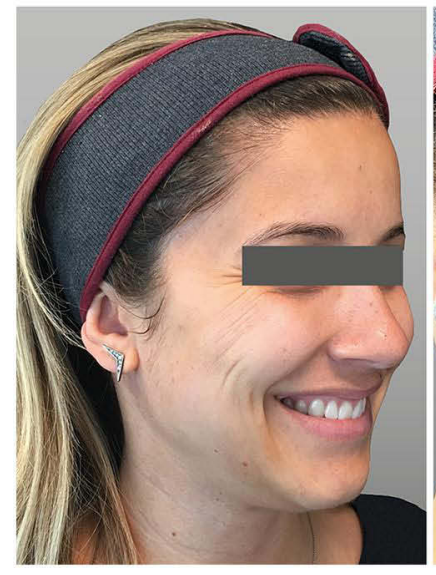

B

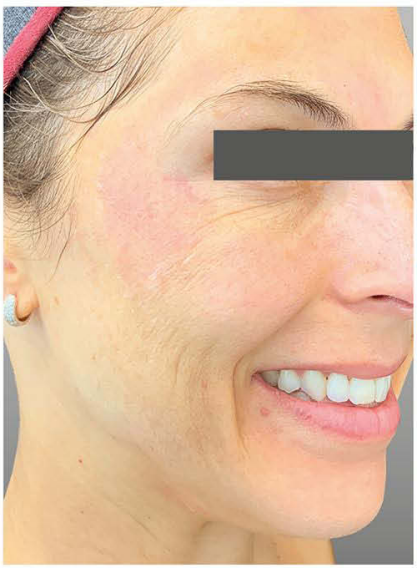

C

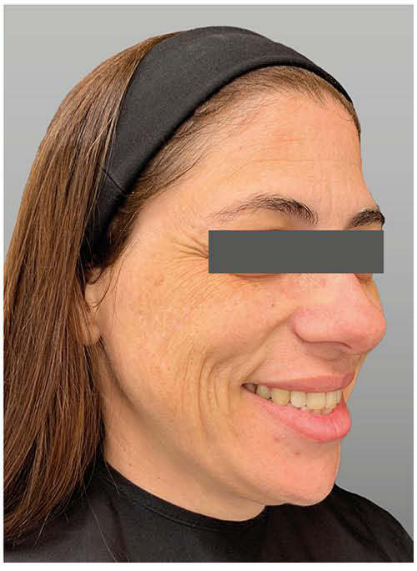

Figure 9 Types of radial cheek lines. (A) Type I lines: structural deficiencies. (B) Type 2 lines: skin laxity. (C) Type 3 lines: structural deficiency plus skin laxity. Courtesy of Carla Pecora, MD.

temporal compartments, which produced a lifting effect when filled. To take advantage of these different effects, the boundaries of the different compartments must be respected when performing filler injections (Figure 10).

\section{Product and Injection Technique}

Radial cheek lines occur in highly dynamic areas, and so resilience of the product is very important. Type 1 lines require lifting and volume augmentation to reduce the wrinkles for which CPM-HA I and CPM-HA V have the ideal rheologic properties (high elasticity and plasticity) (Table 7). Treatment begins in the lateral cheek with supraperiosteal injection of two small boluses of CPM-HA I $(0.2 \mathrm{~mL} /$ injection point) with a $27 \mathrm{G}$ needle or $22-25 \mathrm{G}$ cannula to enhance bone support over the zygomatic arch (Figure 11). To volumize the medial cheek, CPM-HA V is injected in the deep medial cheek fat pad using a $22-25 \mathrm{G}$ cannula (some preferred $22 \mathrm{G}$ because of proximity of facial vein and infraorbital vessels) and 1.0-1.5 mL of product per side with a fanning technique (Figure 11).

In patients with type 2 lines, the approach is dermal volume replacement and hence improved tissue quality, including skin elasticity, texture, and reflectance. ${ }^{25} \mathrm{CPM}-$ HA B is injected with a $30 \mathrm{G}$ needle using the blanching technique $^{19}$ with multiple punctures. The total volume injected will vary according to the severity of the lines but will range from $0.5-1.0 \mathrm{~mL} /$ side. In patients with very thin skin or very superficial lines CPM-HA S $(0.5 \mathrm{~mL} /$ 


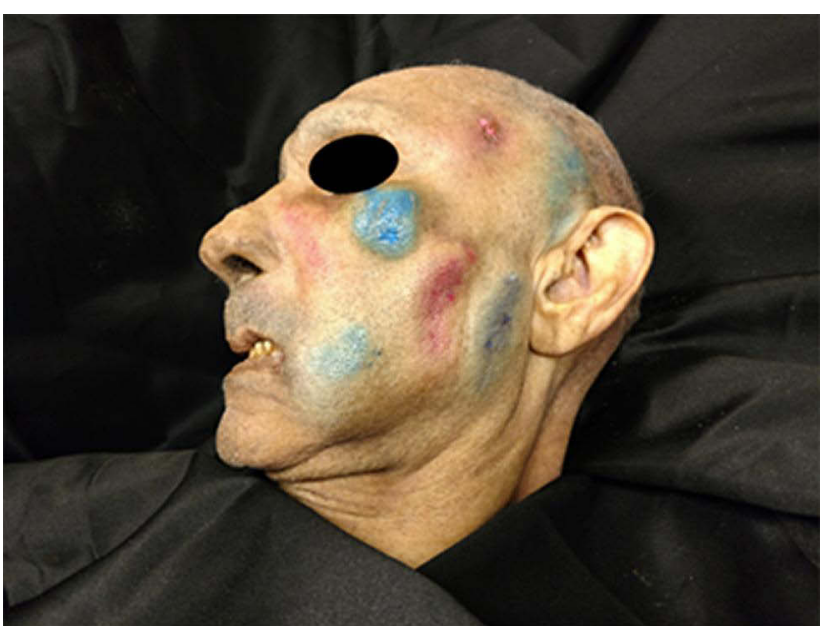

Figure 10 Image shows the left side of a male body donor after the superficial fat compartments have been injected as described previously. ${ }^{24}$ Note the clear boundaries between the respective fat pads when filled with coloured fluid. Courtesy of Sebastian Cotofana.

side) may be preferred combined with neurotoxin treatment of the platysma. ${ }^{23}$

In some cases, a combination of CMP-HA B injected with a $30 \mathrm{G}$ needle and CPM-HA $\mathrm{S}$ injected with the INViSIBLE NEEDL ${ }^{\text {TM }}$ (the thinnest available aesthetic needle) could be recommended.
Patients with type 3 lines lack both structural support and collagen and require a combined approach. In the first session, this will involve re-establishing the structural bone support and volume of the deep fat pads to reduce the signs of age-related changes in the middle and lower face. In the second session, the remaining radial cheek lines will be treated directly. ${ }^{26}$

\section{Avoidance of Complications}

The facial artery often runs on bone at the mandible in the antegonial notch, working its way up more superficially into the subcutaneous plane once it passes the oral commissure. Care must be taken when injecting. Injectors should also know the location of the angular and infraorbital arteries. In case of severe elastosis and very deep, scar-like wrinkles, ablative procedures might be performed in advance of the filler procedures.

\section{Lower Face Indications}

\section{Labiomandibular Sulcus (Marionette Lines) and Sunken Corners of the Mouth Landmark Deficiencies}

The marionette lines run from the oral commissure to the mandible and form the prejowl sulcus following the medial

Table 7 Recommendations for Radial Cheek Lines

\begin{tabular}{|c|c|c|c|c|c|}
\hline Indication & $\begin{array}{l}\text { Product/Needle or } \\
\text { Cannula Size }\end{array}$ & Volume & $\begin{array}{l}\text { Injection } \\
\text { Plane }\end{array}$ & Technique & $\begin{array}{l}\text { Avoidance of } \\
\text { Complications }\end{array}$ \\
\hline $\begin{array}{l}\text { Type I lines } \\
\text { (due to } \\
\text { structural } \\
\text { deficiencies) }\end{array}$ & $\begin{array}{l}\text { CPM-HA I/27G needle or } \\
22-25 G \text { cannula }\end{array}$ & $\begin{array}{l}0.2 \mathrm{~mL} / \\
\text { injection point; } \\
0.1 \mathrm{~mL} / \text { bolus }\end{array}$ & Supraperiosteal & $\begin{array}{l}2 \text { small boluses injected in lateral cheek } \\
\text { to enhance bone support over } \\
\text { zygomatic arch and along angle of the } \\
\text { mandible and mandibular ramus }\end{array}$ & \multirow[t]{4}{*}{$\begin{array}{l}\text { Avoid facial, } \\
\text { angular and } \\
\text { infraorbital } \\
\text { arteries }\end{array}$} \\
\hline $\begin{array}{l}\text { Type I lines } \\
\text { (due to } \\
\text { structural } \\
\text { deficiencies) }\end{array}$ & $\begin{array}{l}\text { CPM-HA V/22-25G } \\
\text { cannula }\end{array}$ & $\begin{array}{l}1.0-1.5 \mathrm{~mL} / \mathrm{side} \text {; } \\
0.1 \mathrm{~mL} / \text { thread }\end{array}$ & $\begin{array}{l}\text { Deep medial } \\
\text { cheek fat pad } \\
\text { or Ristow's } \\
\text { space }\end{array}$ & $\begin{array}{l}\text { For medial cheek volumizing product is } \\
\text { injected in the fat pad using a fanning } \\
\text { technique and along post-jowl sulcus; } \\
\text { combine with neurotoxin treatment of } \\
\text { platysma }\end{array}$ & \\
\hline $\begin{array}{l}\text { Type } 2 \text { lines } \\
\text { (due to skin } \\
\text { laxity) }\end{array}$ & $\begin{array}{l}\text { CPM-HA B/30G needle }{ }^{\dagger} \\
\text { CPM-HA S/INViSIBLE } \\
\text { needle may be used in } \\
\text { patients with very thin skin } \\
\text { or very superficial lines, }\end{array}$ & $\begin{array}{l}0.5-1.0 \mathrm{~mL} / \text { side } \\
\text { depending on } \\
\text { severity; } 0.01- \\
0.02 \mathrm{~mL} / \text { droplet }\end{array}$ & $\begin{array}{l}\text { Superficial } \\
\text { reticular } \\
\text { dermis }\end{array}$ & $\begin{array}{l}\text { Blanching technique, multiple punctures; } \\
\text { combine with botulinum neurotoxin } \\
\text { treatment of platysma }\end{array}$ & \\
\hline $\begin{array}{l}\text { Type } 3 \text { lines } \\
\text { (due to } \\
\text { structural } \\
\text { deficiencies } \\
\text { and skin laxity) }\end{array}$ & $\begin{array}{l}\text { CPM-HA I/CPM-HA-V and } \\
\text { CPM-HA B /CPM-HA S }\end{array}$ & $\begin{array}{l}\text { According to } \\
\text { selected } \\
\text { product see } \\
\text { above }\end{array}$ & $\begin{array}{l}\text { According to } \\
\text { selected } \\
\text { product see } \\
\text { above }\end{array}$ & $\begin{array}{l}\text { According to selected product see } \\
\text { above (combined with neurotoxin } \\
\text { treatment of platysma) }\end{array}$ & \\
\hline
\end{tabular}

Note: Level of consensus: Strong. 'Majority agreement. 

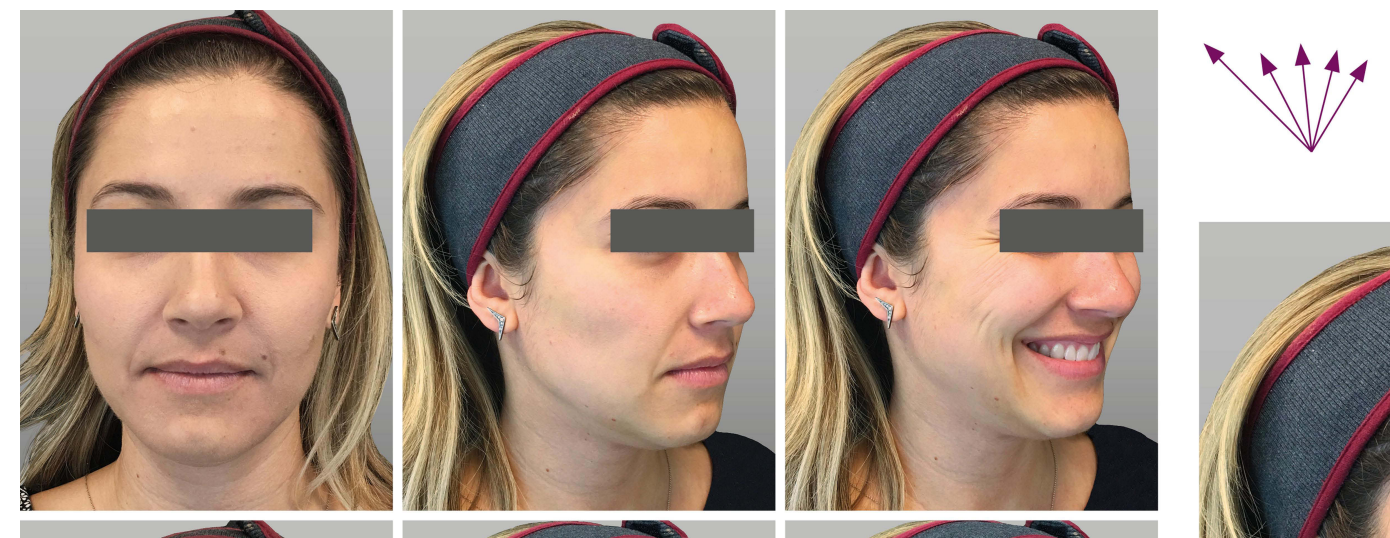

Belotero Volume

$0,2 \mathrm{ml} /$ arrow Total: $1 \mathrm{ml} /$ side
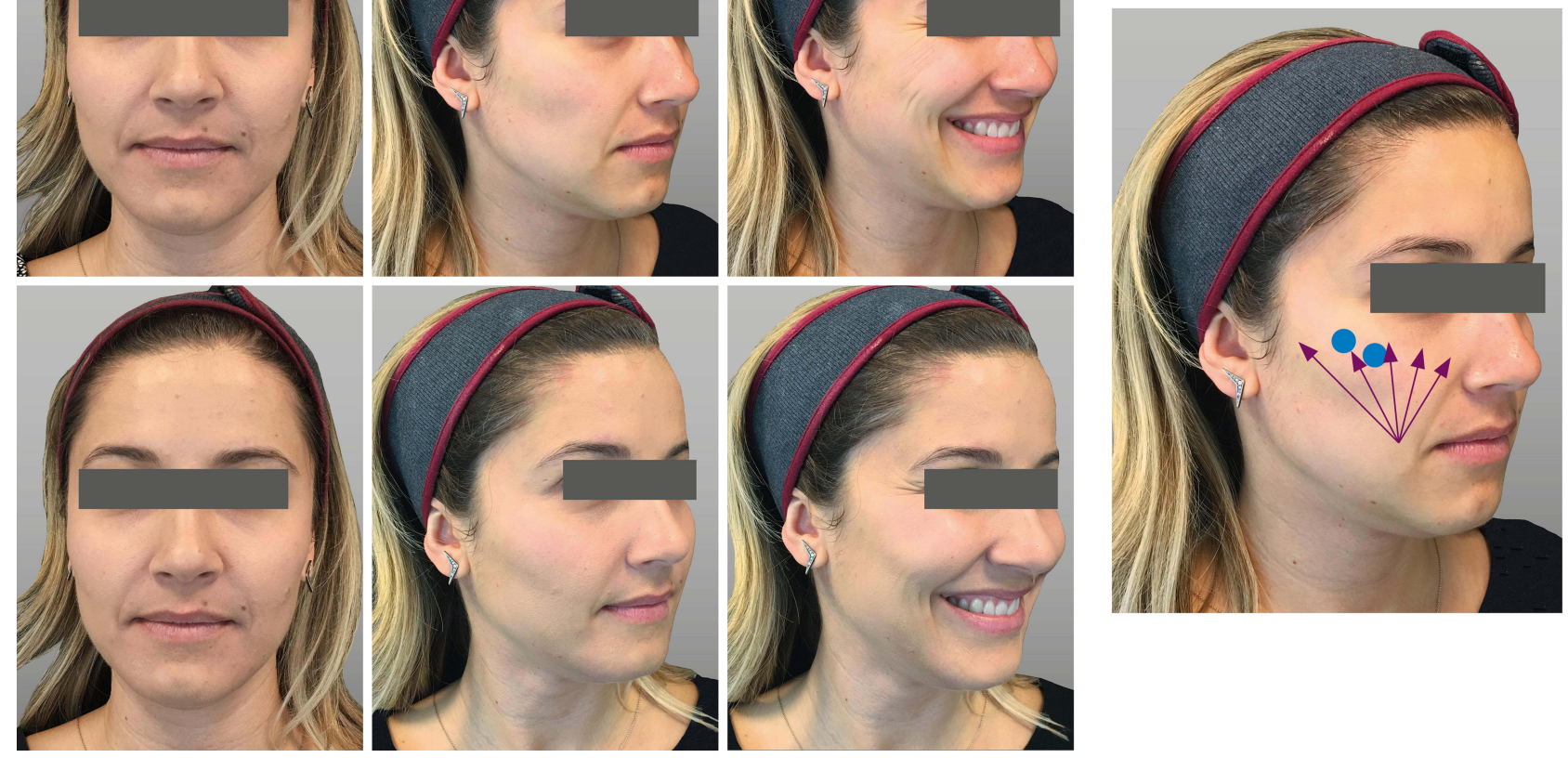

Figure II A 32-year old patient with radial cheek lines caused by lack of bone support but no photodamage (type I lines). In a single session, treatment with two small boluses $(0.2 \mathrm{~mL})$ of CPM-HA I supraperiosteal on the cheekbone and I $\mathrm{mL}$ of CPM-HA $\vee$ injected subcutaneously with a fanning technique will improve the situation. Courtesy of Carla Pecora, MD.

border of the depressor anguli oris muscle, which is where the platysma interdigitates. Sunken corners of the mouth represent the uppermost part of the marionette lines.

\section{Anatomical Considerations}

The marionette lines are influenced by several different aging-related changes in the lower face. The maxilla, mandible and the teeth provide support for the overlying tissues of the lower face, but changes in this skeletal support with age result in descent of the overlying fat pads, and lines and folds appearing in areas where the muscles attach to the skin. This has been illustrated in a paper that examined perioral wrinkles before and after dentures were fitted in edentulous patients. ${ }^{27}$ The structural support provided by the dentures significantly improved the appearance of the perioral lines including marionette lines without any other aesthetic treatments being performed.

The marionette lines are also at the intersection of two different types of subcutaneous tissue arrangements. Lateral to the marionette lines are the subcutaneous superior and inferior jowl fat compartments, whereas medial to the marionette lines there are multiple connections between the dermis, muscle and underlying soft tissues, which allow the dermis to move according to muscle function in this highly mobile area. ${ }^{28}$ At the top of this intersection is the modiolus, which is where all the perioral muscles converge. It is continuous with the platysma which interdigitates with the depressor anguli oris (DAO) muscle and a portion of the orbicularis oris muscle. With skeletal volume loss, there is therefore a greater pull on the platysma and DAO, which ultimately influences the position of the corner of the mouth.

\section{Product and Injection Technique}

In light of the above anatomical considerations, experts agreed that marionette lines should only be treated after volume loss of the maxilla and mandible have been addressed. For lines remaining after treatment of other areas the selected product would depend on line severity. For superficial lines the experts recommended CPM-HA B up to $0.5 \mathrm{~mL} /$ side injected with an intradermal blanching technique (Table 8). For more severe lines, the consensus was for CPM-HA I injected subdermally from the prejowl sulcus and advancing towards the top of the marionette line.

For sunken corners of the mouth, all experts agreed that this represents a tertiary area of injection. Authors agreed that they would preferably use CPM-HA I, but CPM-HA V or 
Table 8 Recommendations for Marionette Lines and Sunken Corners of the Mouth

\begin{tabular}{|c|c|c|c|c|c|}
\hline Indication & $\begin{array}{l}\text { Product/Needle or } \\
\text { Cannula Size }\end{array}$ & Volume & Injection Plane & Technique & $\begin{array}{l}\text { Avoidance of } \\
\text { Complications }\end{array}$ \\
\hline $\begin{array}{l}\text { Marionette } \\
\text { lines }\end{array}$ & $\begin{array}{l}\text { CPM-HA B/30G needle } \\
\text { CPM-HA } 1 / 27 G \text { needle } \\
\text { or } 25 \text { or } 22 \text { cannula }\end{array}$ & $\begin{array}{l}\text { Up to } 0.5 \\
\mathrm{~mL} / \text { side; } \\
0.0 \mathrm{I}-0.02 \\
\mathrm{~mL} / \mathrm{droplet} \\
0.5 \mathrm{~mL} / \\
\text { side; } 0.1 \\
\mathrm{~mL} / \text { thread }\end{array}$ & $\begin{array}{l}\text { Superficial dermis } \\
\text { Subdermal }\end{array}$ & $\begin{array}{l}\text { Blanching technique, multiple punctures for } \\
\text { superficial lines. } \\
\text { Entry point at prejowl sulcus and advancing } \\
\text { towards oral commissure. Alternative entry } \\
\text { point is in medial chin. }\end{array}$ & \multirow[t]{2}{*}{$\begin{array}{l}\text { Avoid facial } \\
\text { artery }\end{array}$} \\
\hline $\begin{array}{l}\text { Sunken } \\
\text { corners of } \\
\text { mouth }\end{array}$ & $\begin{array}{l}\text { CPM-HA I 27G needle, } \\
\text { (CPM-HA V 27-30G } \\
\text { needle or CPM-HA B } \\
\text { 30G needle) }\end{array}$ & $\begin{array}{l}0.1 \mathrm{~mL} \\
\text { boluses; } \\
0.05-0.2 \\
\mathrm{~mL} / \text { side }\end{array}$ & $\begin{array}{l}\text { Subdermal (CPM- } \\
\text { HA I and CPM-HA } \\
\text { V) or intradermal } \\
\text { (CPM-HA B) }\end{array}$ & $\begin{array}{l}\text { Considered tertiary areas of injection after all } \\
\text { other deficits addressed. Use remaining } \\
\text { product to inject lateral lower and upper } \\
\text { vermilion border. }\end{array}$ & \\
\hline
\end{tabular}

Note: Level of consensus: Strong.

CPM-HA B can also be used interchangeably depending on availability of residual product that is left after all other deficits have been addressed. Injections of small boluses $(0.1 \mathrm{~mL})$ are made into the lateral corner of the lower vermilion border, upper vermilion border and then perpendicular to the lip to project the corners of the mouth (Figure 12).

\section{Avoidance of Complications}

The facial artery generally runs about $1 \mathrm{~cm}$ lateral to the oral commissure and is connected to the modiolus by a muscular band of the buccinator muscle. ${ }^{29}$

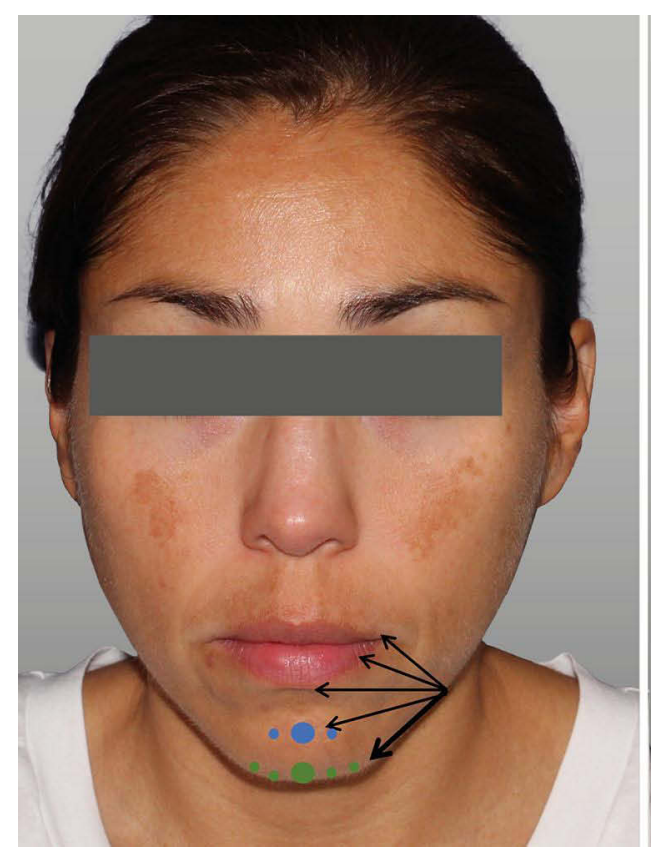

\section{Chin}

\section{Landmark Deficiencies}

Augmentation of the chin is a powerful tool to improve facial harmony, and the treatments may widen or elongate the chin and thus alter facial shape. ${ }^{30}$ Patients presenting for chin enhancement generally fall into two categories. ${ }^{31}$ The first group consists mainly of younger patients who have either a genetically under-formed chin or who are looking to improve their appearance by making their face shape more feminine or masculine. The second group comprises older patients whose chin shape may have changed because of bone

Figure 12 Marionette lines - injection technique. Arrows represent linear retrograde strands of dermal filler and circles represent boluses. Courtesy of Sabrina Fabi, MD. 


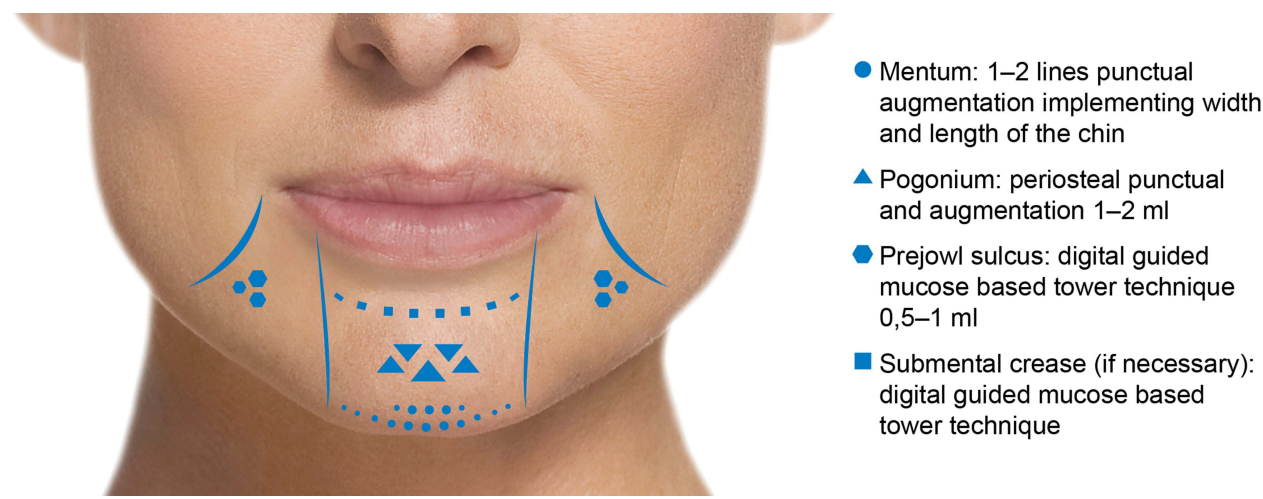

Figure I3 Injection points for chin elongation and chin projection.

resorption and/or soft tissue atrophy. There are also ethnic preferences, for example, Asian patients often request a chin treatment that creates a more heart-shaped face.

\section{Anatomical Considerations}

In Western cultures, the ideal width of the female chin is approximately the same width as the intercanthal distance. In men the chin is wider and approximately the width of the mouth. Care must be taken not to masculinize a female face by making the chin too wide. The ascending mental artery runs in the subdermal plane in a paramedian vertical direction, whereas the mental artery runs horizontally in the supraperiosteal plane after emerging from its foramen. The mental artery connects via multiple periosteal branches to the submandibular artery, which are frequently found in the deep plane deep to mentalis muscle.

\section{Product and Injection Technique Chin Elongation}

Elongating the chin can be effective for balancing facial proportions $^{30}$ and involves injection of the menton (Figure 13). The preferred product is CPM-HA I because of its high elasticity and projection properties (Table 9). A total amount of $1-2 \mathrm{~mL}$ is injected with either a blunt cannula (22G) or needle (27-30G) as multiple boluses in 1-2 lines on the periosteum along the inferior border of the mandible until the required chin length and width is achieved. Before and after photos of a patient treated for chin elongation are shown in Figure 14.

\section{Chin Projection}

To obtain an ideal chin projection in relation to the vermillion, ${ }^{30}$ injections are placed in the pogonion area (Figure 13). The preferred product is CPM-HA V (1-2 $\mathrm{mL})$, injected with either a blunt cannula $(22-25 \mathrm{G})$ and epiperiosteal (deep fat) injection, or needle (27-30G) using the tower technique (Table 9). Before and after photographs of a patient treated for chin projection are shown in Figure 15. Patients with a strong mentalis muscle may require botulinum toxin to relax the muscle before beginning chin augmentation, ideally 10-14 days in advance. In Asian patients with a strong mentalis and a thick skin a two-step injection approach may be

Table 9 Recommendations for Chin Augmentation

\begin{tabular}{|l|l|l|l|l|l|}
\hline Indication & $\begin{array}{l}\text { Product/ } \\
\text { Needle or } \\
\text { Cannula Size }\end{array}$ & Volume & Injection Plane & Technique & $\begin{array}{l}\text { Avoidance of } \\
\text { Complications }\end{array}$ \\
\hline $\begin{array}{l}\text { Chin } \\
\text { elongation } \\
\text { and width }\end{array}$ & $\begin{array}{l}\text { CPM-HA I/22- } \\
25 \mathrm{G} \text { cannula or } \\
27 \mathrm{G} \text { needle }\end{array}$ & $\begin{array}{l}\mathrm{I}-2 \mathrm{~mL} ; \\
0.1-0.2 \\
\mathrm{~mL} / \mathrm{bolus}\end{array}$ & Periosteum & $\begin{array}{l}\text { Inject multiple boluses in I-2 lines along inferior } \\
\text { border of mandible. }\end{array}$ & $\begin{array}{l}\text { Use blunt tip cannula } \\
\text { with slow injection of } \\
\text { multiple boluses }\end{array}$ \\
\hline $\begin{array}{l}\text { Chin } \\
\text { projection }\end{array}$ & $\begin{array}{l}\text { CPM-HA V/22- } \\
25 \mathrm{G} \text { cannula or } \\
27-30 \mathrm{G} \text { needle }\end{array}$ & $\begin{array}{l}\mathrm{I}-2 \mathrm{~mL} ; \\
0 . \mathrm{I}-0.2 \\
\mathrm{~mL} / \mathrm{bolus}\end{array}$ & $\begin{array}{l}\text { Epiperiosteal } \\
\text { (cannula), } \\
\text { periosteum } \\
\text { upwards (needle) }\end{array}$ & $\begin{array}{l}\text { Inject pogonion using multi-level technique } \\
\text { (Sandwich technique with the cannula or Tower } \\
\text { technique with the needle). }\end{array}$ & \\
\hline
\end{tabular}

Note: Level of consensus: Strong. 

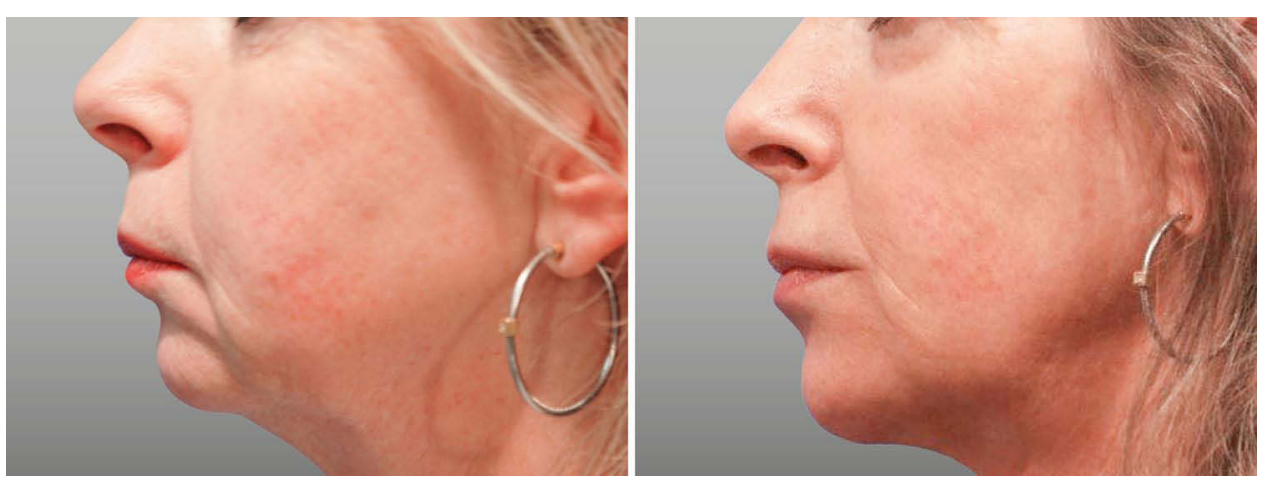

Figure 14 Before and after photos of a patient treated for chin elongation. Courtesy of Sonja Sattler, MD.
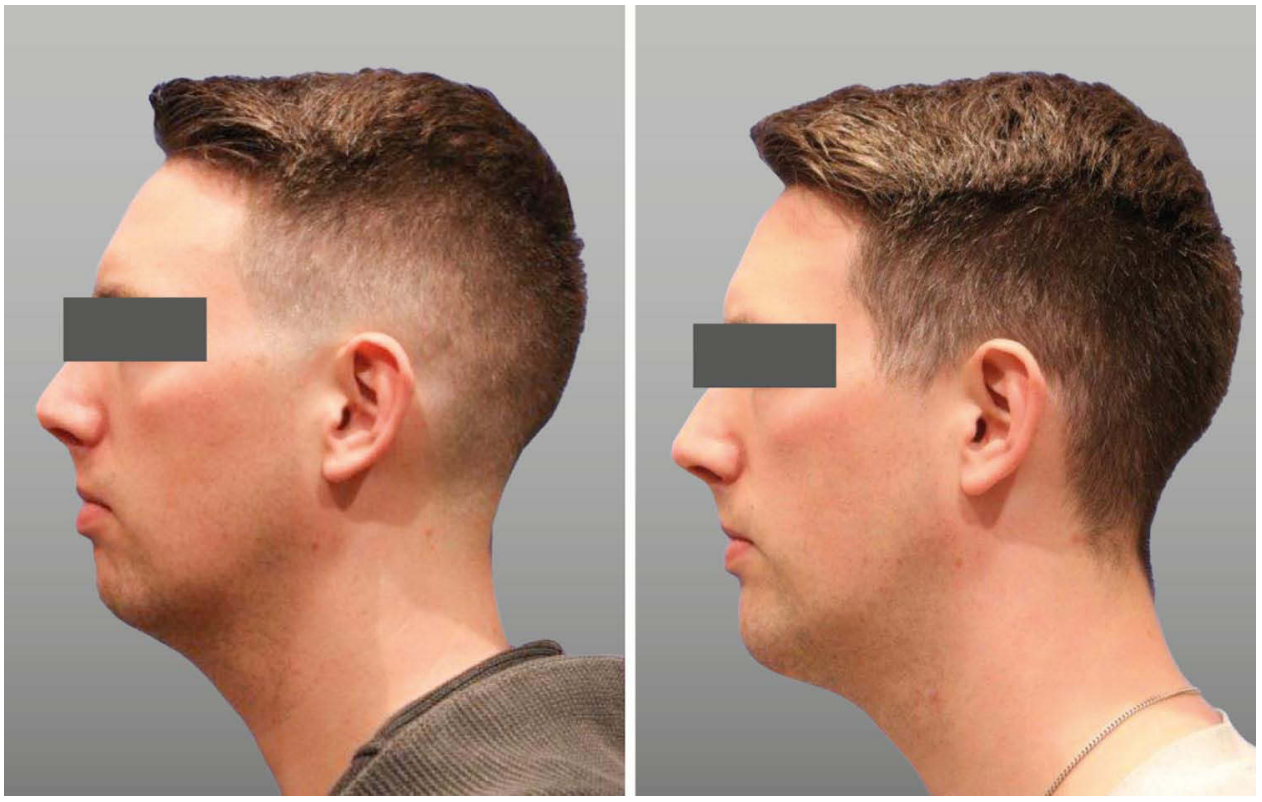

Figure 15 Before and after photos of a patient treated for chin projection. Courtesy of Sonja Sattler, MD.

necessary injecting up to $2 \mathrm{~mL}$ of the product in each session. In patients requiring both elongation and projection, elongation should be performed first followed by projection.

\section{Avoidance of Complications}

Due to anastomoses in chin arterial circulation (mental artery, inferior labial artery, labiomental artery), use of a blunt tip cannula is recommended with slow injection of multiple boluses to minimize risks.

\section{Jawline}

Chin and jawline treatments are generally performed together (with the chin treated first) as the two areas must be blended to ensure smooth contours.

\section{Landmark Deficiencies}

With age, bone resorption, soft tissue descent and skin laxity result in a loss of definition of the jawline with jowl formation, irregular contours and blunting of the mandibular angle. ${ }^{13}$

\section{Anatomical Considerations}

Bone resorption results in decreases in mandibular body height, ramus height and mandibular body length, all of which cause the mandibular angle to move medially along with the soft tissues that are attached to the bone. ${ }^{13}$ Jawline treatment should therefore focus on restoring age-related bone loss and submuscular aponeurotic system (SMAS) tension. Injections in the jowl fat should be 
Table I0 Recommendations for the Jawline

\begin{tabular}{|l|l|l|l|l|l|}
\hline Indication & $\begin{array}{l}\text { Product/ } \\
\text { Needle or } \\
\text { Cannula Size }\end{array}$ & Volume & $\begin{array}{l}\text { Injection } \\
\text { Plane }\end{array}$ & Technique & Avoidance of Complications \\
\hline Jawline & $\begin{array}{l}\text { CPM-HA I } \\
22-25 G \text { cannula } \\
\text { or 27G needle }\end{array}$ & $\begin{array}{l}2 \mathrm{~mL} / \\
\text { side; } 0.1 \\
\mathrm{~mL} / \\
\text { bolus }\end{array}$ & Subcutaneous & $\begin{array}{l}\text { Insertion points at } \\
\text { mandibular angle and jowl } \\
\text { (or prejowl sulcus) }\end{array}$ & $\begin{array}{l}\text { Avoid facial, external carotid arteries, parotid gland } \\
\text { and facial veins. Between chin and mandibular angle } \\
\text { inject subcutaneous }\end{array}$ \\
\hline
\end{tabular}

Note: Level of consensus: Strong.

avoided as they can accentuate the boundary between the different types of subcutaneous arrangements that form the sulcus $^{13}$ and thereby lead to a more masculine appearing chin.

\section{Product and Injection Technique}

For defining the jawline, the consensus was for the injection of CPM-HA I. Two insertion points are recommended (Table 10). The first is at the mandibular angle with injections in the subdermal plane and directed towards the zygomatic arch and tragus, with a supraperiosteal bolus at the mandibular angle itself (performed with a $27 \mathrm{G}$ needle) (Figure 16A). The second is at the prejowl sulcus (Figure 16B), medial to the vessels with injections performed subdermally towards the mandibular angle using a $27 \mathrm{G} 50 \mathrm{~mm}$ or $70 \mathrm{~mm}$ stiff cannula (the vessels can be crossed as they are deep and the cannula subdermal. The direction is then changed, and injections performed towards the chin, using subdermal linear threading and placing a small bolus on the bone at the origin of the mandibular ligament. No product should be injected into the jowl fat. Before and after photos of a patient treated for the jawline are shown in Figure 17.

\section{Avoidance of Complications}

Both the facial and the external carotid arteries run deep in the jawline area; the facial artery runs over the periosteum just anterior to the masseter muscle and the external carotid artery runs deep to the mandible, dorsal to the ramus. If injecting at the chin or mandibular angle, injections can be performed supraperiosteally, but injections at points in between these landmarks should therefore be subcutaneous. Care must also be taken to avoid the parotid gland, facial veins and stenson's duct, which are located sub-SMAS and lie over the masseter muscle.

\section{Lip Contouring, Volumizing and Perioral Lines \\ Landmark Deficiencies}

Lack of lip definition may be congenital or associated with aging. An optimal lip contour comprises a well-defined upper and lower vermilion border, cupids bow, and a

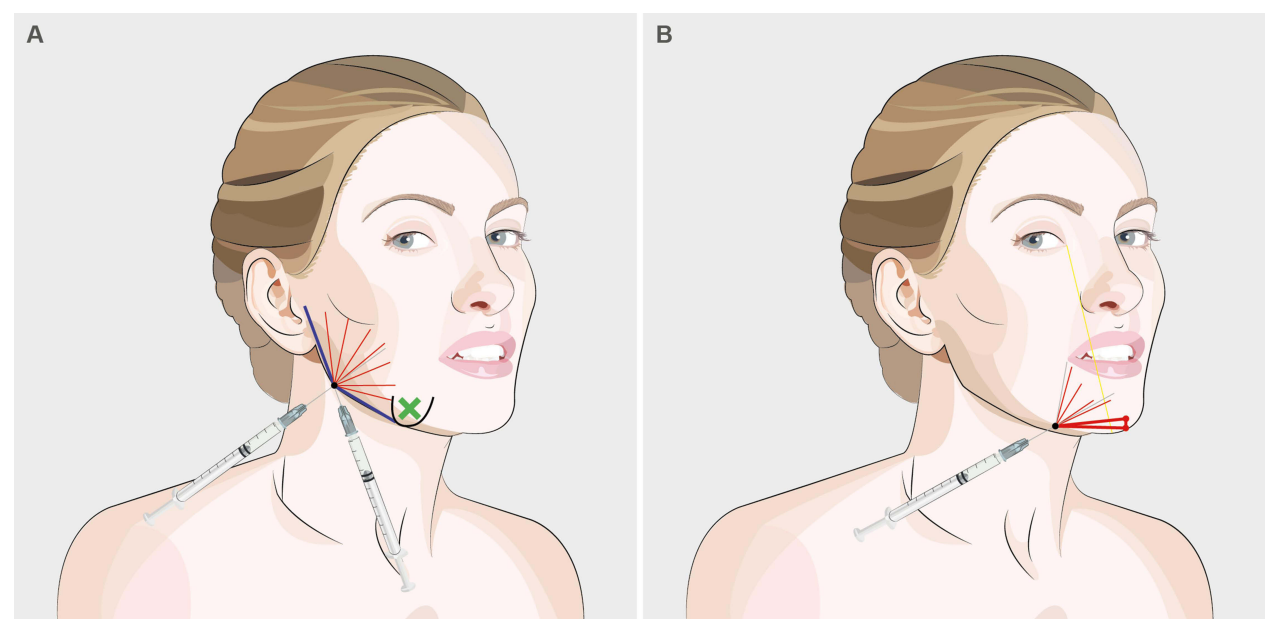

Figure 16 Injection points for jawline rejuvenation with non-traumatic cannula. (A) Mandibular angle entry point; (B) Pre-jowl sulcus entry point. Schematics @ Dr. Jani van Loghem. 


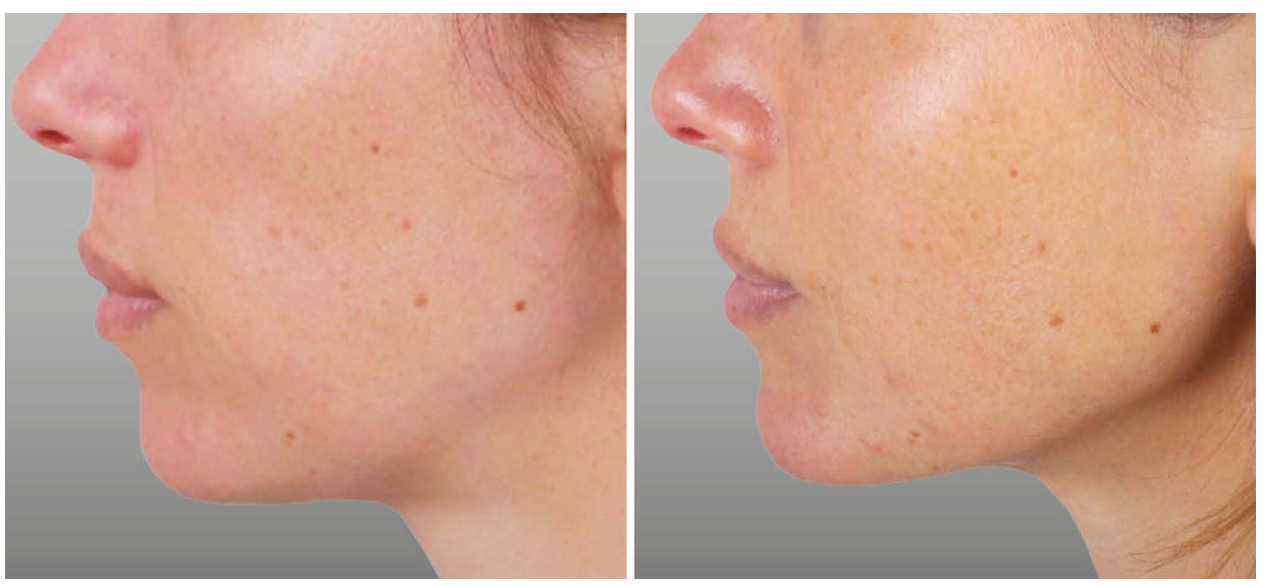

Figure 17 Before and after photos of a patient treated for jawline rejuvenation. Courtesy Jani van Loghem, MD. Patient was also treated in other facial indications.

J-shaped curve to the upper lip. ${ }^{32}$ In younger patients, the vermilion border, especially in the upper lip, is usually well defined, but definition is lost with age because of elongation of the upper lip and photo damage. ${ }^{33}$ A lack of definition along the vermilion border can accentuate the appearance of perioral lines (smokers' lines). ${ }^{34}$

In addition to lip contouring, enhancement of lip volume is one of the most frequently demanded aesthetic indications, particularly in younger patients. ${ }^{35}$ Other popular indications in this age group include lip hydration and lip projection. Most patients prefer a natural aesthetic improvement, but some may request a more visible lip augmentation. Injectors should not be pressured into performing a procedure they believe is unaesthetically pleasing and should try to convince patients that overfilled lips are not a desirable aesthetic result.

\section{Anatomical Considerations}

The lips are very well vascularized and therefore injected product is never far from a vessel. In a recent anatomical study, a range of injection techniques commonly used to treat the lips with either a needle or cannula were examined for subsequent placement of product. The results revealed that injected material was frequently placed near the labial arteries, thus representing a high risk for intraarterial events. ${ }^{32}$ The vasculature of the lips is also highly variable, and the course of the superior and inferior labial arteries within the upper and lower lips is not always submucosal (between the oral mucosa and the orbicularis oris muscle). ${ }^{36}$ A study of 193 cadavers reported labial artery position as submucosal in $78.1 \%$ of cases, intramuscular in $17.5 \%$ of cases, and subcutaneous in $2.1 \%$ of cases. The course of the arteries also switched between planes at least once in around a third of the cadavers, with the greatest variability observed in the midline location. As a result, injections should be performed in the subdermal plane in the lateral aspect of the lips and care should be taken when augmenting around the midline.

With age, it is not necessarily lip volume that is lost, but instead a repositioning of the existing volume due to increasing lip length because of skeletal changes. ${ }^{37}$ These patients do not require volumizing but architectural restructuring and contouring to re-establish shape, which can be achieved by injecting a matrix of filler threads.

Emphasis should be placed on tailoring treatment with consideration given to landmarks such as the medial tubercle and recreation of the J-shape. Treatments should also be performed with appropriate ethnic considerations. There are large differences in lip proportions between African, Latin American, Asian and Caucasian ethnic groups, for example in relation to vermilion height and lip protrusion. ${ }^{38,39}$ The vermilion border is not a primary concern in south-east Asian patients but is popular in middle-eastern patients.

\section{Product and Injection Technique Lip Contouring}

Prior to injection, patients should be assessed for both lip contour (vermilion border) and lip volume as one has an influence on the other. For restoring upper lip contour and a J-shape on lateral view, all experts recommended CPMHA LC (Table 11). This product has been intentionally designed with high cohesivity and low elasticity to allow the lips to be contoured without creating too much outward projection. It is injected as threads of $<0.05 \mathrm{~mL}$ (needle) or $0.1-0.2 \mathrm{~mL} /$ side (cannula) with an entry point just lateral to the oral commissure. Experts were divided 
Table I I Recommendations for the Lips

\begin{tabular}{|c|c|c|c|c|c|}
\hline & $\begin{array}{l}\text { Product/Needle or Cannula } \\
\text { Size }\end{array}$ & Volume & $\begin{array}{l}\text { Injection } \\
\text { Plane }\end{array}$ & Technique & $\begin{array}{l}\text { Avoidance of } \\
\text { Complications }\end{array}$ \\
\hline Lip contouring & $\begin{array}{l}\text { CPM-HA LC/25G cannula or } 30 G \\
\text { needle }^{\dagger}\end{array}$ & $\begin{array}{l}<0.05 \mathrm{~mL} \text { threads } \\
\text { (needle), } 0.1-0.2 \\
\mathrm{~mL} / \text { side (cannula) }\end{array}$ & $\begin{array}{l}\text { Superficial } \\
\text { dermis }\end{array}$ & $\begin{array}{l}\text { Injection along vermilion } \\
\text { border. Entry point for the } \\
\text { cannula just lateral to the } \\
\text { oral commissure }\end{array}$ & \multirow{6}{*}{$\begin{array}{l}\text { Avoid inferior and } \\
\text { superior labial } \\
\text { arteries. } \\
\text { When volumizing } \\
\text { safest zone is } \\
\text { subcutaneous plane of } \\
\text { lateral upper and } \\
\text { lower lip }\end{array}$} \\
\hline \multicolumn{5}{|l|}{ Lip Volumizing } & \\
\hline $\begin{array}{l}\text { Volumizing } \\
\text { vermilion }\end{array}$ & $\begin{array}{l}\text { CPM-HA LS or CPM-HA I } \\
\text { depending on the amount needed } \\
\text { (CPM-HA LC is an option for minor } \\
\text { improvements) } 25 \mathrm{G} \text { cannula }\end{array}$ & $\begin{array}{l}0.5-1.0 \mathrm{~mL} / \text { side of } \\
\text { upper or lower lip; } \\
0.05-0.1 \mathrm{~mL} / \\
\text { retrograde thread }\end{array}$ & Subdermal & $\begin{array}{l}\text { Inject as a series of linear } \\
\text { threads (not bolus). }\end{array}$ & \\
\hline Restructuring & $\begin{array}{l}\text { CPM-HA LS or CPM-HA I (CPM- } \\
\text { HA LC is an option) depending on } \\
\text { the amount needed } \\
25 \text { G cannula }\end{array}$ & $\begin{array}{l}0.3-0.5 \mathrm{~mL} / \text { side of } \\
\text { upper or lower lip; } \\
0.05-0.1 \mathrm{~mL} / \\
\text { thread }\end{array}$ & & $\begin{array}{l}\text { CPM-HA I preferred for } \\
\text { subcutaneous placement } \\
\text { to give anterior lip } \\
\text { projection }\end{array}$ & \\
\hline Perioral lines & CPM-HA LC/30G needle & $\begin{array}{l}<0.0 \mathrm{I} / \text { point; } 0.5- \\
1.0 \mathrm{~mL} \text { total }\end{array}$ & $\begin{array}{l}\text { Superficial } \\
\text { dermis }\end{array}$ & $\begin{array}{l}\text { Blanching technique, } \\
\text { multiple punctures }\end{array}$ & \\
\hline $\begin{array}{l}\text { Philtral } \\
\text { columns }\end{array}$ & $\begin{array}{l}\text { CPM-HA LS or CPM-HA B/30G } \\
\text { needle }\end{array}$ & $\begin{array}{l}0.05-0.1 \mathrm{~mL} / \mathrm{side} \text { in } \\
\text { a retrograde linear } \\
\text { thread }\end{array}$ & Intradermal & $\begin{array}{l}\text { Retrograde linear threads } \\
\text { from the base of the } \\
\text { philtral column at the } \\
\text { vermilion border }\end{array}$ & \\
\hline
\end{tabular}

Note: Level of consensus: Strong. ${ }^{\dagger}$ Experts were divided on whether a cannula or $30 \mathrm{G}$ needle should be used for the upper lip vermilion border.

on whether a $25 \mathrm{G}$ cannula or $30 \mathrm{G}$ needle should be used. While needles may be used for lateral aspects, caution should be used around the midline and the tip of the needle kept in view. Figure 18A and B shows before and after images of a patient treated with lip contouring.

\section{Lip Volumizing}

When classified according to the Merz Aesthetics lip fullness scale, ${ }^{40}$ experts would volumize lips of grades 0 to 3 , and with exception to grade 4. For volumizing the vermilion, CPM-HA LS is preferred (Table 11). For a natural look, no more than $0.5-1.0 \mathrm{~mL}$ should be injected per side. Product should be injected with a needle $(30 \mathrm{G})$ or cannula $(25 \mathrm{G}, 38$ or $40 \mathrm{~mm})$ as a series of linear threads and not as a bolus. ${ }^{5}$ For restructuring the older lip, CPM-HA LS is preferred for submucosal projection to correct bone resorption, but
A

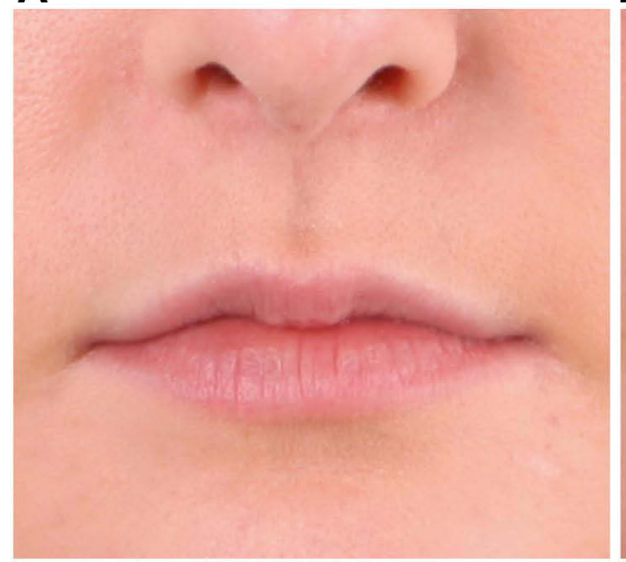

B

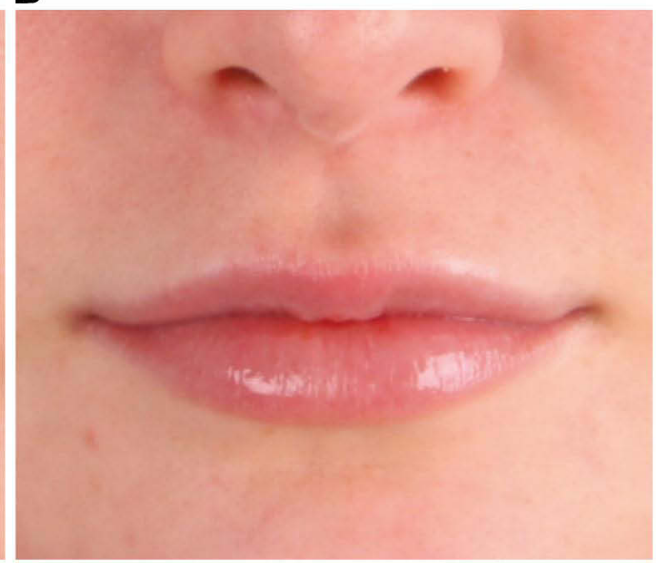

Figure 18 Before (A) and after (B) photos of lip contouring. Patient also received lip volumizing. Courtesy Dr. Jani van Loghem. 
Table 12 Recommendations for Skin Revitalization

\begin{tabular}{|c|c|c|c|c|c|}
\hline $\begin{array}{l}\text { Skin } \\
\text { Revitalisation }\end{array}$ & $\begin{array}{l}\text { Product/ } \\
\text { Needle or } \\
\text { Cannula } \\
\text { Size }\end{array}$ & Volume & $\begin{array}{l}\text { Injection } \\
\text { Plane }\end{array}$ & Technique & $\begin{array}{l}\text { Avoidance of } \\
\text { Complications }\end{array}$ \\
\hline & $\begin{array}{l}\text { CPM-HA S/ } \\
32 \mathrm{G} 4 \mathrm{~mm} \\
\text { needle or } \\
30 \mathrm{G} \text { needle } \\
\text { CPM-HA } \\
\mathrm{R} / 32 \mathrm{G} \\
4 \mathrm{~mm} \\
\text { needle or } \\
\text { 30G needle }\end{array}$ & $\begin{array}{l}0.02-0.05 \mathrm{~mL} / \text { bolus; I } \mathrm{mL} / \text { side (face); } 0.5 \\
\mathrm{~mL} / \text { back of the hand; I mL/side of the } \\
\text { hand; I mL/session perioral; I mL/session } \\
\text { neck; } 2-3 \mathrm{~mL} \text { per session for the decollete } \\
0.02 \mathrm{~mL} \text { per droplet }\end{array}$ & $\begin{array}{l}\text { Immediate } \\
\text { subdermis }\end{array}$ & $\begin{array}{l}\text { Multiple punctures over } 3 \\
\text { sessions I month apart with } \\
\text { maintenance sessions every } 6 \\
\text { months } \\
\text { Injections spaced I cm apart. } \\
\text { Treatment delivered in } 3 \\
\text { sessions I month apart and } \\
\text { thereafter by maintenance } \\
\text { sessions every } 8-12 \text { months }\end{array}$ & $\begin{array}{l}\text { Avoid large } \\
\text { boluses with } \\
\text { blanching } \\
\text { technique }\end{array}$ \\
\hline
\end{tabular}

Note: CPM-HA R is currently only available in Europe and as a result non-European consensus members did not have experience with this product.

CPM-HA LC may also be used at a volume of $0.3-0.5 \mathrm{~mL} /$ side. Restructuring of the body of the lip should be performed alongside contouring the vermilion border.

\section{Perioral Lines}

Perioral lines can be improved by first contouring the vermilion border as above. Prior to treatment it should also be determined whether the lines are associated with concomitant elastosis, in which case a resurfacing treatment is required. If there is no elastosis, the experts recommended injection of CPM-HA B with a $30 \mathrm{G}$ needle using a blanching technique and injecting $<0.01$ per point along the static perioral lines (Table 11). CPM-HA S could also be used with the INViSIBLE needle, or both CPMHA B and CPM-HA S in combination using a sandwich technique. If elastosis is also present, the recommendation was to wait at least 2 weeks before performing resurfacing techniques with energy-based devices. ${ }^{41}$

\section{Philtral Columns}

To define the philtral columns and improve the lateral view of the lips, the recommendation was for intradermal (dermal/muscle interface)/subdermal injection of $<0.1 \mathrm{~mL}$ CPM-HA B or CPM-HA LC with a needle (Table 11).

\section{Avoidance of Complications}

The superior and inferior labial arteries are at risk for embolization. The safest position for the injection of product when volumizing the lip is in the subcutaneous plane of the lateral upper and lower lip, around the midline these arteries are more frequently found in superficial positions.

\section{Skin Revitalization}

\section{Landmark Deficiencies}

Endogenous HA is important for providing skin hydration and skin turgor, and when levels are reduced can lead to lax and dull-looking skin. ${ }^{42}$ Skin revitalization with microinjections of HA is of benefit to younger patients who notice loss of elasticity, dry and tired looking skin despite a daily skin care routine, but who do not need treatment with volumizing fillers. In older patients, skin revitalization can be combined with all rejuvenation procedures to improve skin quality and elasticity.

\section{Anatomical Considerations}

HA products formulated for skin revitalization can be injected over large treatment areas of the face, neck, décolletage and hands to increase skin hydration, surface smoothness, elasticity and glow. In addition, the multiple small depots of HA activate fibroblasts promoting new collagen and elastin formation. ${ }^{43,44}$ Injections are not targeting specific wrinkles but treating the face as a whole to improve skin quality and therefore are not recommended to be injected using the blanching technique.

\section{Product and Injection Technique}

Using CPM-HA $\mathrm{S}$ the injection protocol typically takes place over three sessions each spaced 1 month apart, followed by a maintenance phase of one session approximately every 6 months (Table 12). Injections are performed with a $32 \mathrm{G}$ short needle in the mid to deep dermis or in the immediate subdermis. In addition to improving skin quality, potential other indications for this technique include reducing pore size $\mathrm{e}^{45}$ and improving melasma. 
CPM-HA R, the newest addition to the CPM-HA range, is a slightly crosslinked HA $(20 \mathrm{mg} / \mathrm{mL})$ with added glycerol $(17.5 \mathrm{mg} / \mathrm{mL})$ that has been intentionally formulated to improve skin hydration, elasticity, firmness and glow. The addition of glycerol as a humectant provides deep and immediate hydration. ${ }^{46}$ In a 36 -week study, 25 patients received injections in the lower cheek area at 4-week intervals. ${ }^{47}$ Patients noticed improved skin hydration beginning in the first week after treatment, which continued to improve up to week 36 . They also noted a gradual increase in glow (seen as a reduction in redness) over 36 weeks.

CPM-HA R should be injected with a $32 \mathrm{G}$ short needle or the so-called INViSIBLE needle in the immediate subdermis. The injection amount is approximately 0.02 $\mathrm{mL}$ per droplet with injections spaced $1 \mathrm{~cm}$ apart. In the CPM-HA R study, patients each received 20 micropuncture treatments of $50 \mu \mathrm{L}$ into the lower cheek in three sessions spaced 1 month apart followed by a maintenance session 8-12 months later. However, treatment sessions should be individualized according to patients' skin quality (Table 12). A topical anesthetic should be applied in advance in sensitive patients.

\section{Avoidance of Complications}

No subcutaneous injections should be performed with the needle because of proximity to the vessels, especially in the area around the nasolabial fold. Avoid large boluses with the blanching technique as the papules might be visible and palpable for several days.

\section{Summary}

HA fillers play an increasingly important role in minimallyinvasive aesthetic procedures and a wide range of products is now available to injectors. The CPM-HA range has been developed to allow injectors to tailor their treatments with products that have optimal rheological properties for a defined indication from deep volumizing to skin revitalization. The range is characterized by several differentiators. The cohesive polydensified matrix (CPM) crosslinking technology enables products to be intentionally manufactured with different proportions of crosslinking density, providing the range with the cohesivity required for seamless, natural tissue integration. In the case of CPM-HA S and CPM-HA B, the blanching technique allows the product to be placed very superficially. The high cohesivity of CPM-HA I provides it with resistance to dynamic stress making it ideal for lifting and contouring, and the high elasticity and plasticity of CPMHA V make it ideal for volumizing and projection.

The tissue layers into which these products are placed and the way they are injected has a significant effect on treatment results. Based on the anatomical landmarks, specific treatment techniques have been suggested to reduce the risk of serious adverse events, and in particular arterial embolization. Upper face CPM-HA indications include the forehead, temples, and superior orbital hollows. Injections are performed with blunt-tipped cannulas with product placed supraperiosteal in the forehead, subdermal in the temples, and deep to the orbicularis oculi muscle in the superior orbital hollows. In the mid face, indications include infraorbital hollows, pre-auricular hollowing, and radial cheek lines. Blunt-tipped cannulas are preferred for infraorbital and pre-auricular injections with periosteal and subdermal injection depths, respectively, For radial cheek lines, injections can be performed with a needle or cannula, injection depth will depend on whether the lines are due to structural deficiencies and/or skin laxity. In the lower face, indications include marionette lines, chin, jawline and the lips. Injections of the chin and jawline can be performed with a needle or cannula and should be supraperiosteal at the chin and subcutaneous along the jawline. For the marionette lines, injections may be performed with a needle or cannula and are subdermal; the blanching technique can also be used for superficial lines. For lip contouring, product is placed in the superficial dermis and for lip volumizing, product is placed subdermal. Both procedures may be performed with a needle or cannula. Finally, for skin revitalization, product is injected with a needle in the immediate subdermis.

The CPM-HA gels contain zones of high and low density due to the variable extent of cross-linking, conveying each gel with specific properties. Thus, while high cohesivity is a feature of the range and maintains product integrity, those with a greater proportion of firmer, high density zones such as CPM-HA-V and CPM-HA-I have high plasticity and provide a volumizing effect while remaining malleable. Gels with high cohesivity and lower viscosity such as CPM-HA-B are softer and have seamless and natural dermal integration and are appropriate for more superficial layers where it is necessary to avoid skin irregularities, lumps, and the Tyndall effect. Specific formulations have also been developed for the lips and for skin revitalizing. For most of the above indications product choice will also depend on factors such as the severity of the concavity and patient characteristics including skin thickness and degree of skin laxity. 
This consensus document has been prepared to guide clinicians in the selection of products, administration techniques and depths of injection for the specific indication with the aim of providing seamless and natural treatment results, enhanced safety and patient satisfaction. It is anticipated that injectors will use the knowledge in this document to individualize treatments for their patients and thus achieve optimal aesthetic outcomes.

\section{Acknowledgments}

This paper was uploaded to the University of Amsterdam repository as a thesis on 28 October 2020 . https://pure.uva.nl/ ws/files/51368933/Thesis.pdf. ${ }^{48}$ This is a company sponsored submission based on the results of a company sponsored advisory board meeting held in 2019 by Merz Aesthetics.

\section{Disclosure}

Dr Jani van Loghem reports personal fees from Merz Aesthetics, during the conduct of the study; personal fees from Merz Aesthetics, outside the submitted work. Dr Gabriela Casabona reports personal fees from MERZ, outside the submitted work. Professor Sebastian Cotofana reports personal fees from Merz Pharmaceuticals, outside the submitted work. Professor Sabrina Guillen Fabi reports grants from Merz, during the conduct of the study; and she is a consultant and speaker and investigator for Merz, Galderma and AbbVie. Dr Kate Goldie reports personal fees for consultancy from Merz Pharma. Professor Martina Kerscher reports personal fees for performing clinical trials; is Advisory Board member and speaker for Merz Pharmaceuticals, has performed clinical trials for Galderma/qmed, is Advisory Board member for Allergan/ AbbVie, during the conduct of the study. Dr Carla de Sanctis Pecora reports non-financial support for serving in the advisory board for Merz Aesthetics, during the conduct of the study; personal fees as a speaker for Merz Aesthetics, outside the submitted work. Dr Ada Trindade de Almeida reports grants as consultant and speaker from Merz. Dr Tatjana Pavicic reports personal fees for participation in advisory board from Merz Aesthetics, during the conduct of the study; grants, personal fees for clinical studies, lectures, participations in Advisory Boards from Merz Aesthetics, grants for clinical studies from LG, personal fees, non-financial support for lectures, participations in Advisory Boards, and device testing from AAT, outside the submitted work. The authors report no other conflicts of interest in this work.

\section{References}

1. Falcone SJ, Berg RA. Crosslinked hyaluronic acid dermal fillers: a comparison of rheological properties. J Biomed Mater Res A. 2008;87(1):264-271. doi:10.1002/jbm.a.31675

2. Sundaram H, Cassuto D. Biophysical characteristics of hyaluronic acid soft-tissue fillers and their relevance to aesthetic applications. Plast Reconstr Surg. 2013;132(4Suppl 2):5S-21S. doi:10.1097/ PRS.0b013e31829d1d40

3. Tran C, Carraux P, Micheels P, Kaya G, Salomon D. In vivo biointegration of three hyaluronic acid fillers in human skin: a histological study. Dermatology. 2014;228(1):47-54. doi:10.1159/000354384

4. Gavard Molliard S, Albert S, Mondon K. Key importance of compression properties in the biophysical characteristics of hyaluronic acid soft-tissue fillers. J Mech Behav Biomed Mater. 2016;61:290298. doi:10.1016/j.jmbbm.2016.04.001

5. Pavicic T, Webb KL, Frank K, Gotkin RH, Tamura B, Cotofana S. Arterial wall penetration forces in needles versus cannulas. Plast Reconstr Surg. 2019;143(3):504e-512e. doi:10.1097/PRS.00000 00000005321

6. Sherris DA, Larrabee WF. Forehead. In: Principles of Facial Reconstruction: A Subunit Approach to Cutaneous Repair. 2nd ed. USA: Thieme Medical Publishers, Inc.; 2009.

7. Anido J, Arenas D, Arruabarrena C, et al. Tailored botulinum toxin type A injections in aesthetic medicine: consensus panel recommendations for treating the forehead based on individual facial anatomy and muscle tone. Clin Cosmet Investig Dermatol. 2017;10:413-421. doi:10.2147/CCID.S138274

8. Frank K, Gotkin RH, Pavicic T, et al. Age and gender differences of the frontal bone: a Computed Tomographic (CT)-based study. Aesthet Surg J. 2018. doi:10.1093/asj/sjy270

9. Cotofana S, Mian A, Sykes JM, et al. An update on the anatomy of the forehead compartments. Plast Reconstr Surg. 2017;139(4):864e872e. doi:10.1097/PRS.0000000000003174

10. Khan TT, Colon-Acevedo B, Mettu P, DeLorenzi C, Woodward JA. An anatomical analysis of the supratrochlear artery: considerations in facial filler injections and preventing vision loss. Aesthet Surg J. 2017;37(2):203-208. doi:10.1093/asj/sjw132

11. Pavicic T, Mohmand HM, Yankova M, et al. Influence of needle size and injection angle on the distribution pattern of facial soft tissue fillers. J Cosmet Dermatol. 2019;18(5):1230-1236. doi:10.1111/ jocd.13066.

12. Juhász ML, Marmur ES. Temporal fossa defects: techniques for injecting hyaluronic acid filler and complications after hyaluronic acid filler injection. $J$ Cosmet Dermatol. 2015;14(3):254-259. doi: $10.1111 /$ jocd. 12155

13. Suwanchinda A, Rudolph C, Hladik C, et al. The layered anatomy of the jawline. J Cosmet Dermatol. 2018;17(4):625-631. doi:10.1111/ jocd. 12728

14. Casabona G, Frank K, Moellhoff N, et al. Full-face effects of temporal volumizing and temporal lifting techniques. $J$ Cosmet Dermatol. 2020;19(11):2830-2837. doi:10.1111/jocd.13728

15. Cotofana S, Koban K, Pavicic T, et al. Clinical validation of the surface volume coefficient for minimally invasive treatment of the temple. J Drugs Dermatol. 2019;18(6):533.

16. Goodman GJ, Magnusson MR, Callan P, et al. A consensus on minimizing the risk of hyaluronic acid embolic visual loss and suggestions for immediate bedside management. Aesthet Surg J. 2019;40(9):sjz312. doi:10.1093/asj/sjz312

17. van Loghem JA, Humzah D, Kerscher M. Cannula versus sharp needle for placement of soft tissue fillers: an observational cadaver study. Aesthet Surg J. 2017;38(1):73-88.

18. Morley AM, Taban M, Malhotra R, Goldberg RA. Use of hyaluronic acid gel for upper eyelid filling and contouring. Ophthalmic Plast Reconstr Surg. 2009;25(6):440-444. doi:10.1097/IOP.0b013 e3181b80eb8 
19. Micheels P, Sarazin D, Besse S, Sundaram H, Flynn TC. A blanching technique for intradermal injection of the hyaluronic acid Belotero. Plast Reconstr Surg. 2013;132(4Suppl 2):59S-68S. doi:10.1097/ PRS.0b013e31829a02fb

20. Lee JH, Hong G. Definitions of groove and hollowness of the infraorbital region and clinical treatment using soft-tissue filler. Arch Plast Surg. 2018;45(3):214-221. doi:10.5999/aps.2017.01193

21. Mojallal A, Cotofana S. Anatomy of lower eyelid and eyelid-cheek junction. Ann Chir Plast Esthet. 2017;62(5):365-374. doi:10.1016/j. anplas.2017.09.007

22. Funt DK. Avoiding malar edema during midface/cheek augmentation with dermal fillers. J Clin Aesthet Dermatol. 2011;4(12):32-36.

23. De Almeida A, Romiti A, Carruthers J. The facial platysma and its underappreciated role in lower face dynamics and contour. Dermatol Surg. 2017;43(8):1042-1049. doi:10.1097/DSS.0000000000001135

24. Schenck TL, Koban KC, Schlattau A, et al. The functional anatomy of the superficial fat compartments of the face: a detailed imaging study. Plast Reconstr Surg. 2018;141(6):1351-1359. doi:10.1097/ PRS.0000000000004364

25. Sundaram H, Fagien S. cohesive polydensified matrix hyaluronic acid for fine lines. Plast Reconstr Surg J. 2015;136(5S):149S-163S. doi:10.1097/PRS.0000000000001835

26. Suwanchinda A, Webb KL, Rudolph C, et al. The posterior temporal supraSMAS minimally invasive lifting technique using soft-tissue fillers. J Cosmet Dermatol. 2018;17(4):1-8.

27. Lupi SM, Cislaghi M, Rizzo S, Rodriguez y Baena R. Rehabilitation with implant-retained removable dentures and its effects on perioral aesthetics: a prospective cohort study. Clin Cosmet Investig Dent. 2016;30(8):105-110

28. Ghassemi A, Prescher A, Riediger D, Axer H. Anatomy of the SMAS revisited. Aesthetic Plast Surg. 2003;27(4):258-264. doi:10.1007/ s00266-003-3065-3

29. Thomaidis VK. Cutaneous Flaps in Head and Neck Reconstruction: From Anatomy to Surgery, Lips and Chin. 2014:265.

30. Wilson M, Jones I, Butterwick K, Fabi SG. The role of nonsurgical chin augmentation in full face rejuvenation: a review and our experience. Derm Surg. 2018;44(7):985-993.

31. Lee EI. Aesthetic alteration of the chin. Semin Plast Surg. 2013;27 (3):155-160. doi:10.1055/s-0033-1357113

32. Ghannam S, Sattler S, Frank K, et al. Treating the lips and its anatomical correlate in respect to vascular compromise. Facial Plast Surg. 2019;35(2):193-203. doi:10.1055/s-0039-1683856

33. Wollina U. Perioral rejuvenation: restoration of attractiveness in aging females by minimally invasive procedures. Clin Interv Aging. 2013;8:1149-1155. doi:10.2147/CIA.S48102

34. Hotta TA. Understanding the perioral anatomy. Plast Surg Nurse J. 2016;36(1):12-18. doi:10.1097/PSN.0000000000000126

35. Sarnoff DS, Gotkin RH. Six steps to the "perfect" lip. J Drugs Dermatol. 2012;11(9):1081-1088.

36. Cotofana S, Pretterklieber B, Lucius R, et al. Distribution pattern of the superior and inferior labial arteries: impact for safe upper and lower lip augmentation procedures. Plast Reconstr Surg. 2017;139 (5):1075-1082. doi:10.1097/PRS.0000000000003244

Clinical, Cosmetic and Investigational Dermatology

\section{Publish your work in this journal}

Clinical, Cosmetic and Investigational Dermatology is an international, peer-reviewed, open access, online journal that focuses on the latest clinical and experimental research in all aspects of skin disease and cosmetic interventions. This journal is indexed on CAS
37. Ramaut L, Tonnard P, Verpaele A, Verstraete K, Blondeel P. Aging of the upper lip: part I: a retrospective analysis of metric changes in soft tissue on magnetic resonance imaging. Plast Reconstr Surg. 2019;143 (2):440-446. doi:10.1097/PRS.0000000000005190

38. de Freitas LM, de Freitas KM, Pinzan A, Janson G, de Freitas MR. A comparison of skeletal, dentoalveolar and soft tissue characteristics in white and black Brazilian subjects. J Appl Oral Sci. 2010;18(2):135142. doi:10.1590/S1678-77572010000200007

39. Wen YF, Wong HM, Lin R, Yin G, McGrath C. Inter-ethnic/racial facial variations: a systematic review and bayesian meta-analysis of photogrammetric studies. PLoS One. 2015;10(8):e0134525. doi:10.1371/journal.pone.0134525

40. Carruthers A, Carruthers J, Hardas B, et al. A validated lip fullness grading scale. Dermatol Surg. 2008;34(Suppl 2):S161-6.

41. Fabi SG, Burgess C, Carruthers A, et al. Consensus recommendations for combined aesthetic interventions using botulinum toxin, fillers, and microfocused ultrasound in the neck, décolletage, hands, and other areas of the body. Dermatol Surg. 2016;42(10):1199-1208. doi:10.1097/DSS.0000000000000869

42. Bukhari SN, Roswandi NL, Waqas M, et al. Hyaluronic acid, a promising skin rejuvenating biomedicine: a review of recent updates and pre-clinical and clinical investigations on cosmetic and nutricosmetic effects. Int J Biol Macromol. 2018;120(Pt B):1682-1695. doi:10.1016/j.ijbiomac.2018.09.188

43. Wang F, Garza LA, Kang S, et al. In vivo stimulation of de novo collagen production caused by cross-linked hyaluronic acid dermal filler injections in photodamaged human skin. Arch Dermatol. 2007;143(2):155-163. doi:10.1001/archderm.143.2.155

44. França Wanick FB, Almeida Issa MC, Luiz RR, Soares Filho PJ, Olej B. Skin remodeling using hyaluronic acid filler injections in photoaged faces. Dermatol Surg. 2016;42(3):352-359. doi:10.1097/ DSS.0000000000000659

45. Qian W, Zhang YK, Hou Y, et al. Effect analysis of intradermal hyaluronic acid injection to treat enlarged facial pores. $J$ Cosmet Dermatol. 2018;17(4):596-599. doi:10.1111/jocd.12385

46. Korponyai C, Szél E, Behány Z, et al. Effects of locally applied glycerol and xylitol on the hydration, barrier function and morphological parameters of the skin. Acta Derm Venereol. 2017;97(2):182187. doi: $10.2340 / 00015555-2493$

47. Hertz-Kleptow D, Hanschmann A, Hofmann M, Reuther T, Kerscher M. Facial skin revitalization with $\mathrm{CPM}^{\circledR}$-HA20G: an effective and safe early intervention treatment. Clin Cosmet Investig Dermatol. 2019;12:563-572. doi:10.2147/CCID.S209256

48. van Loghem JAJ. Improving patient safety during facial filler treatments in aesthetic medicine; 2020. Available from: https://pure.uva nl/ws/files/51368933/Thesis.pdf. Accessed July 27, 2021.
The manuscript management system is completely online and includes a very quick and fair peer-review system, which is all easy to use. Visit http://www.dovepress.com/testimonials.php to read real quotes from published authors. 